\title{
Extracellular Signal-Regulated Kinase (ERK) Controls Immediate Early Gene Induction on Corticostriatal Stimulation
}

\author{
Véronique Sgambato, Christiane Pagès, Monique Rogard, Marie-Jo Besson, and Jocelyne Caboche \\ Laboratoire Neurochimie-Anatomie, Institut des Neurosciences, Unité Mixte de Recherche 7624, Université Pierre et \\ Marie Curie, 75005 Paris, France
}

\begin{abstract}
Activity-dependent changes in neuronal structure and synaptic remodeling depend critically on gene regulation. In an attempt to understand how glutamate receptor stimulation at the membrane leads to gene regulation in the nucleus, we traced intracellular signaling pathways targeting DNA regulatory elements of immediate early genes (IEGs). For this purpose we used an in vivo electrical stimulation of the glutamatergic corticostriatal pathway. We show that a transient activation of extracellular signal-regulated kinase (ERK) proteins (detected by immunocytochemistry with an anti-active antibody) is spatially coincident with the onset of IEG induction [c-fos, zif 268, and map kinase phosphatase-1 (MKP-1) detected by in situ hybridization] in the striatum, bilaterally. Both Elk-1 and CREB transcription factors (targeting SRE and CRE DNA regulatory elements, respectively) were hyperphosphorylated in register with ERK activation and IEG mRNA induction. However, their hyperphosphorylation oc-
\end{abstract}

curred in different subcellular compartments: the cytoplasm and the nucleus for Elk-1 and the nucleus for CREB. The role of the ERK signaling cascade in gene regulation was confirmed after intrastriatal and unilateral injection of the specific ERK inhibitor PD 98059, which completely abolished c-fos, zif 268, and MKP-1 mRNA induction in the injected side. Of interest, both Elk-1 and CREB hyperphosphorylation also was impaired after PD 98059 injection. Thus two different ERK modules, one depending on the cytoplasmic activation of Elk-1 and the other one depending on the nuclear activation of CREB, control IEG transcriptional regulation in our model. Our findings provide significant insights into intracellular mechanisms underlying synaptic plasticity in the striatum.

Key words: motor cortex; striatum; c-fos; zif 268; transcription factors; Elk-1; CREB; phosphorylation; ERK; kinases; phosphatases
In the CNS, activity-dependent changes in gene expression can elicit long-term adaptive responses underlying synaptic plasticity (Sheng and Greenberg, 1990; Ginty et al., 1992; Ghosh and Greenberg, 1995; Ginty, 1997). Glutamate, which is involved in long-term potentiation (LTP), regulates the transcription of immediate early genes (IEGs) such as c-fos. Two DNA regulatory elements, at least, are crucial for this transcriptional regulation: the cAMP/calcium-responsive element (CRE) and the serumresponsive element (SRE) (Bading et al., 1993; Miranti et al., 1995; Xia et al., 1996; Johnson et al., 1997). The CRE site is controlled by the phosphorylation of the CRE binding protein (CREB) on residue Ser $^{133}$ by cAMP-dependent kinase (PKA) (Gonzalez and Montminy, 1989) and calcium/calmodulindependent protein kinases (CaMKs) (Dash et al., 1991; Sheng et al., 1991; Matthews et al., 1994; Sun et al., 1994).

Calcium signaling at the SRE DNA regulatory element is still an enigma. This site is required for serum-induced c-fos expression (Treisman, 1992) in the context of mitotic cell regulation. Together with flanking DNA sequences, it serves as sites for the assembly of multiprotein complexes that include a dimer of serum response factor (SRF) (Treisman, 1986; Norman et al., 1988;

Received June 25, 1998; revised Aug. 10, 1998; accepted Aug. 14, 1998.

This work was supported by the Université Pierre et Marie Curie, the Centre National de la Recherche Scientifique, Institut Lilly, and Biomed Program (PL 962215). V.S. is a doctoral fellow of the Ministere de l'Education Nationale et de l'Enseignement Superieur. We thank Dr. J. M. Deniau for helpful advice; Dr. R. A. Hipskind for critical discussion and for providing c-fos, zif 268, and MKP-1 cDNAs; and Parke Davis for generously providing PD 98059.

Correspondence should be addressed to Dr. Jocelyne Caboche, Laboratoire Neurochimie-Anatomie, Institut des Neurosciences, Unité Mixte de Recherche 7624, Université Pierre et Marie Curie, 9 Quai St. Bernard, 75005 Paris, France. Copyright (C) 1998 Society for Neuroscience $0270-6474 / 98 / 188814-12 \$ 05.00 / 0$
Schröter et al., 1990) and a ternary complex factor (TCF) (Shaw et al., 1989) (for review, see Treisman, 1992, 1995). Although SRF is phosphorylated rapidly in response to mitogenic stimulation and phosphorylation affects its DNA binding properties (Rivera et al., 1993), a major regulatory input received by the SRE is attributed to TCF phosphorylation (Hill et al., 1993). Elk-1, the first TCF to be identified (Hipskind et al., 1991), is phosphorylated rapidly on $\operatorname{Ser}^{383}$ and $\operatorname{Ser}^{389}$ in its C-terminal region in response to the activation of extracellular signalregulated kinase (ERK) proteins (Marais et al., 1993; Hipskind et al., 1994a,b). This increases its ability to form a ternary complex with SRF and SRE (Gille et al., 1992, 1995) and to activate c-fos transcription (Hill et al., 1993; Marais et al., 1993; Zinck et al., 1993; Hipskind et al., 1994a,b; Janknecht et al., 1994).

In postmitotic neurons, ERK proteins are expressed abundantly (Boulton and Cobb, 1991; Fiore et al., 1993a). They can be activated in response to increases in intracellular calcium levels or glutamate receptor stimulation (Bading and Greenberg, 1991; Fiore et al., 1993b; Rosen et al., 1994; Kurino et al., 1995), and this activation is critically required for LTP in rat hippocampus (English and Sweat, 1996, 1997). However, whether ERK activation is required for glutamate-induced gene regulation remains to be established.

We chose the in vivo stimulation of the corticostriatal pathway as a promising model for studying ERK implication in glutamateinduced IEG regulation (Sgambato et al., 1998). Stimulation of glutamatergic cortical afferents (Reubi and Cuenod, 1979) can elicit LTP in striatal neurons in vivo (Charpier and Deniau, 1997). We show here that a transient activation of ERK targeting both Elk-1 and CREB transcription factors in distinct subcellular com- 
partments is critically involved in IEG [c-fos, zif 268, and map kinase phosphatase-1 (MKP-1)] mRNA induction.

\section{MATERIALS AND METHODS}

\section{Corticostriatal stimulations}

After anesthesia with pentobarbital (6 mg/kg, i.p.; Sanofi, Paris, France), cortical electrical stimulations were applied in animals placed in a conventional stereotaxic apparatus. Care was taken to minimize uncontrolled sources of stimulation; the skin around the points of stereotaxic contention and areas of incision were numbed with Xylocaine. Body temperature was monitored throughout the experiment and kept at $37-38^{\circ} \mathrm{C}$ with a homeothermic blanket. A small craniotomy was made over the orofacial area of the motor cortex according to previously described stereotaxic coordinates (Paxinos and Watson, 1986). Orofacial cortical stimulations were applied through pairs of wires (Ni-Chrome, 0.2 $\mathrm{mm}$ diameter) $1.5 \mathrm{~mm}$ apart and inserted at a depth of $1.5 \mathrm{~mm}$ from the cortical surface. Electrical stimuli consisted of trains of pulses of $200 \mu \mathrm{A}$ intensity and $50 \mathrm{msec}$ duration delivered at frequencies of $250 \mathrm{~Hz}$, repeated at $4 \mathrm{~Hz}$ for a period varying from 15 to $60 \mathrm{~min}$. The localization of the jaw area was identified precisely by observing the motor effects evoked by these electrical pulses. The polarity of electrodes was reversed every $30 \mathrm{sec}$ to avoid lesion of cortical tissue. Sham-stimulated rats were treated identically except that no electrical stimulation was delivered. At the end of stimulation, brains were processed for either neuroanatomical (in vivo perfusion with PFA 4\%) or biochemical (rapid extraction of lateral or medial parts of the striatum) studies (see below).

\section{Tissue preparation for in situ hybridization} and immunocytochemistry

Rat brains were fixed by intracardiac perfusion of $4 \%$ paraformaldehyde (PFA) in $0.1 \mathrm{M} \mathrm{Na}_{2} \mathrm{HPO}_{4} / \mathrm{NaH}_{2} \mathrm{PO}_{4}$ buffer, pH 7.5 (phosphate buffer), delivered with a peristaltic pump at $50 \mathrm{ml} / \mathrm{min}$ during $10 \mathrm{~min}$. Brains were removed and post-fixed in the same fixative solution for $2 \mathrm{hr}$, washed overnight in $0.1 \mathrm{M}$ phosphate buffer containing $15 \%$ sucrose, and then frozen in isopentane (for $1 \mathrm{~min}$ at $\left.-25^{\circ} \mathrm{C}\right)$. Sections $(20 \mu \mathrm{m})$ were cut on a microtome and then kept in a solution containing $30 \%$ ethylene glycol, $30 \%$ glycerol, $0.1 \mathrm{~m}$ phosphate buffer, and $0.1 \%$ diethyl pyrocarbonate (DEPC; Sigma, Deisenhofen, Germany) at $-20^{\circ} \mathrm{C}$ until they were processed for in situ hybridization or immunohistochemistry.

\section{Probe synthesis for in situ hybridization}

The antisense (complementary to cellular mRNA) probes used in this study were ${ }^{33} \mathrm{P}$-radiolabeled riboprobes. For c-fos, a 487 bp cDNA subclone corresponding to exon 4 of human cDNA was linearized after HindIII digestion and transcribed with T7 RNA polymerase. For zif 268 riboprobe, a murine zif $268 \mathrm{cDNA}$ subclone corresponding to $1.6 \mathrm{~kb}$ was linearized after HindIII digestion and transcribed with T7 RNA polymerase. MKP-1 riboprobe was transcribed from a murine MKP-1 cDNA subclone corresponding to $663 \mathrm{bp}$ with T7 RNA polymerase after linearization with PstI. Transcription reactions contained $1 \mu \mathrm{M}\left[\alpha^{33} \mathrm{P}\right]$-UTP (3000 Ci/mmol; Isotopchim), $250 \mu \mathrm{M}$ ATP, CTP, and GTP, and unlabeled UTP $(10.5 \mu \mathrm{M})$; the reactions were incubated at $39^{\circ} \mathrm{C}$ for $2 \mathrm{hr}$. After DNase I digestion, the labeled RNA was purified by phenol/chloroform/ isoamyl alcohol (25:24:1) extraction and ethanol precipitation. Gel electrophoresis showed the transcripts to be predominantly full length.

\section{In situ hybridization}

Free-floating sections were mounted on SuperFrost/plus slides (MenzelGläser) in RNase-free conditions. Once dried, the mounted sections were rinsed in PBS and treated for $10 \mathrm{~min}$ with $0.1 \mathrm{~m}$ glycine in $0.1 \mathrm{M}$ Tris- $\mathrm{HCl}$, $\mathrm{pH}$ 7.4. The sections were rinsed for $5 \mathrm{~min}$ at $37^{\circ} \mathrm{C}$ in $0.1 \mathrm{M}$ Tris- $\mathrm{HCl}, \mathrm{pH}$ 8 , and $50 \mathrm{~mm}$ EDTA, and were treated for $15 \mathrm{~min}$ at $37^{\circ} \mathrm{C}$ with $1 \mathrm{mg} / \mathrm{ml}$ proteinase $\mathrm{K}$ in the same buffer. Before hybridization the sections were subjected to the following treatments: post-fixation for $15 \mathrm{~min}$ in $4 \%$ PFA, $5 \mathrm{~mm} \mathrm{MgCl}_{2}$ in PBS at room temperature, acetylation for $20 \mathrm{~min}$ in acetic anhydride/triethanolamine, $\mathrm{pH} 8$, at room temperature, and stepwise dehydration in alcohol. The following hybridization solution was applied on sections, which then were covered with GelBond film (FMC Bioproducts, Rockland, ME). The hybridization mixture contained 200 $\mathrm{ng} / \mathrm{ml}$ (4 ng/section) of ${ }^{33} \mathrm{P}$-RNA probe in $20 \mathrm{~mm}$ Tris- $\mathrm{HCl}, \mathrm{pH} 8,300 \mathrm{~mm}$ $\mathrm{NaCl}, 5 \mathrm{~mm}$ EDTA, $10 \%$ dextran sulfate, $1 \times$ Denhardt's solution $(0.02 \%$ Ficoll, $0.02 \%$ polyvinyl pyrrolidone, and $10 \mathrm{mg} / \mathrm{ml} \mathrm{BSA}), 0.5 \mathrm{mg} / \mathrm{ml}$ Escherichia coli tRNA, 0.1 M dithiothreitol (DTT), and 50\% formamide.
Hybridization was performed at $60^{\circ} \mathrm{C}$ in humid chambers for $16 \mathrm{hr}$. After the GelBond coverslips were removed in $4 \times$ SSC $(1 \times$ SSC is $0.15 \mathrm{M}$ $\mathrm{NaCl} / 0.015 \mathrm{M}$ Na citrate) and $10 \mathrm{~mm}$ DTT, the slides were washed in the same solution for $1 \mathrm{hr}$ at room temperature and then in $50 \%$ formamide, $10 \mathrm{~mm}$ Tris-HCl, $\mathrm{pH} 8,75 \mathrm{~mm} \mathrm{NaCl}$, and $2.5 \mathrm{~mm}$ EDTA. Sections were treated with RNase A $(20 \mu \mathrm{g} / \mathrm{ml}$; Sigma $)$ in $400 \mathrm{~mm} \mathrm{NaCl}, 10 \mathrm{~mm}$ Tris- $\mathrm{HCl}, \mathrm{pH} 7.5$, and $50 \mathrm{~mm}$ EDTA for $1 \mathrm{hr}$ at $37^{\circ} \mathrm{C}$ and then were rinsed for $15 \mathrm{~min}$ at $60^{\circ} \mathrm{C}$ in $2 \times \mathrm{SSC}$, followed by $0.1 \times \mathrm{SSC}$. After dehydration, the sections were air-dried and exposed with Biomax-MR films (Kodak, Rochester, NY) for $3 \mathrm{~d}$ (for zif 268) or $6 \mathrm{~d}$ (for c-fos and MKP-1 probes).

\section{Immunocytochemistry}

The immunohistochemical procedure was adapted from protocols previously described except that, for the detection of phosphorylated proteins, $0.1 \mathrm{~mm} \mathrm{NaF}$ was included in all buffers and incubation solutions.

Day 1. Free-floating sections were rinsed in Tris-buffered saline (TBS; $0.25 \mathrm{M}$ Tris and $0.5 \mathrm{M} \mathrm{NaCl}, \mathrm{pH} 7.5$ ), incubated for $5 \mathrm{~min}$ in TBS containing $3 \% \mathrm{H}_{2} \mathrm{O}_{2}$ and $10 \%$ methanol, and then rinsed three times for $10 \mathrm{~min}$ each in TBS. After a $15 \mathrm{~min}$ incubation in $0.2 \%$ Triton X-100 in TBS, the sections were rinsed three times in TBS. These were incubated with the primary antibody (see below) for $72 \mathrm{hr}$ at $4^{\circ} \mathrm{C}$.

Day 2. After three rinses in TBS, the sections were incubated for $48 \mathrm{hr}$ at $4^{\circ} \mathrm{C}$ with the secondary biotinylated antibody (anti-IgG), using a dilution twice that of the first antibody in TBS.

Day 3. After being washed (three times in TBS), the sections were incubated overnight in avidin-biotin-peroxidase complex (ABC) solution (final dilution, 1:50; Vector Laboratories, Peterborough, UK).

Day 4. The sections were washed two times in TBS and two times in TB $(0.25 \mathrm{M}$ Tris, $\mathrm{pH} 7.5)$ for $10 \mathrm{~min}$ each, placed in a solution of TB containing $0.1 \%$ 3,3'-diaminobenzidine (DAB; $50 \mathrm{mg} / 100 \mathrm{ml}$ ), and developed by $\mathrm{H}_{2} \mathrm{O}_{2}$ addition $(0.02 \%)$. After processing, the tissue sections were mounted onto gelatin-coated slides and dehydrated through alcohol to xylene for light microscopic examination.

\section{Tissue preparation for Western blot analysis}

Day 1. Tissue samples were extracted rapidly from the brain and lysed in solubilization buffer [containing (in mM) 10 Tris- $\mathrm{Cl}, 50 \mathrm{NaCl}, 30$ sodium pyrophosphate, $50 \mathrm{NaF}, 1 \mathrm{DTT}$, and 0.5 benzamidine plus $1 \%$ Triton $\mathrm{X}-100,5 \mu \mathrm{M} \mathrm{ZnCl} 2,100 \mu \mathrm{M} \mathrm{Na} \mathrm{VO}_{4}, 5 \mathrm{~nm}$ okadaic acid, $2.5 \mu \mathrm{g}$ each of aprotinin, pepstatin, and leupeptin, and $0.5 \mu \mathrm{M}$ PMSF]. Insoluble material was removed by centrifugation $\left(13,000 \mathrm{rpm}\right.$ for $20 \mathrm{~min}$ at $\left.4^{\circ} \mathrm{C}\right)$. Cell lysates $(30,20$, or $10 \mu \mathrm{g}$ per lane for the detection of P-Elk-1, P-CREB, and P-ERK, respectively) were separated by $10 \%$ SDS-PAGE before electrophoretic transfer onto polyvinylidene difluoride membrane (PVDF; ICN Biochemicals, Paris, France). The blots were saturated (for $1 \mathrm{hr}$ at room temperature) with BSA (Fraction V, Sigma) $8 \%$ (for P-Elk-1) or 5\% (for P-ERK and P-CREB) and incubated (overnight at $4^{\circ} \mathrm{C}$ ) with the anti-active antibodies (see below).

Day 2. Subsequently, the blots were incubated for $2 \mathrm{hr}$ at room temperature with goat anti-rabbit horseradish peroxydase-conjugated antibodies before exposure to the ECL substrate. Then the blots were stripped (glycine-HCl, $\mathrm{pH} \mathrm{2.8,} \mathrm{two} \mathrm{times} \mathrm{for} 20 \mathrm{~min}$ at $55^{\circ} \mathrm{C}$ ) and saturated overnight in $5 \%$ nonfat dry milk.

Day 3. Then the blots were incubated with the nonactive antibodies (see below). The efficacy of the stripping step was assessed by omitting the first antibody and verifying the lack of signals on the blot.

\section{Antibodies}

The anti-active antibodies used in this study were polyclonal antibodies raised against the dually phosphorylated $\mathrm{Thr} / \mathrm{Glu} / \mathrm{Tyr}$ region within the catalytic core of the active form of p44/ERK1 and p42/ERK2 [and corresponding to $\mathrm{Thr}^{183}-\mathrm{Tyr}^{185}$ in $\mathrm{p} 42 / \mathrm{ERK} 2$ (Promega, Paris, France)], a phospho-Ser ${ }^{133}$ peptide corresponding to residues $129-137$ of human CREB (New England Biolabs, Beverly, MA), and a phosphoSer $^{383}$ peptide corresponding to residues 379-392 of human Elk-1 (New England Biolabs). The dilutions used for immunostaining were 1:100 for P-ERK and P-CREB antisera and 1:80 for P-Elk-1 antiserum. For Western blot analysis the dilutions were 1:2500 for P-ERK antiserum, 1:500 for P-CREB antiserum, and 1:100 for P-Elk-1 antiserum.

The nonactive antibody used for immunostaining (dilution 1:250) was a rabbit anti-ERK antibody raised against a peptide corresponding to the 345-358 region within the $C$ terminus of the rat ERK2 (Santa Cruz Biotechnology). For Western blot analysis the nonactive antibodies used were anti-ERK antibody (1:4000; Santa Cruz Biotechnology), anti-Elk-1 
antibody (1:1000; rabbit polyclonal antibody raised against a recombinant protein corresponding to the C-terminal region of human Elk-1), and anti-CREB antibody raised against a peptide corresponding to residues 123-137 of human CREB (1:1000; New England Biolabs).

\section{Data analysis}

Tissue sections of stimulated rats $(15,30,45$, and $60 \mathrm{~min})$, which were processed for immunocytochemistry by using the anti-active antibodies, were examined under light microscope. P-ERK-, P-Elk-1-, and P-CREBpositive neurons were plotted at $25 \times$ magnification with a computerized image analyzer (Biocom, Paris, France). Cell counts were performed for each rat in the ipsilateral striatum to the cortical stimulation in a total surface area of $2.7 \mathrm{~mm}^{2}$.

\section{Striatal injection of PD 98059}

PD 98059 was dissolved in dimethyl sulfoxide $\left(\mathrm{Me}_{2} \mathrm{SO}\right)$ to obtain a $10 \mathrm{~mm}$ stock solution. Then it was diluted $1: 100$ in $0.9 \% \mathrm{NaCl}$ (final concentration, $100 \mu \mathrm{M})$. The compound was stereotaxically delivered $(6 \mu \mathrm{l})$, unilaterally, in the lateral part of the striatum [bregma: anterior $9 \mathrm{~mm}$, lateral $3.5 \mathrm{~mm}$, and depth $5.5 \mathrm{~mm}$, according to Paxinos and Watson (1986)] by pressure injection through a Hamilton syringe fit with a glass micropipette (internal tip diameter, $50 \mu \mathrm{m}$ ). The injection was made over a total period of $55 \mathrm{~min}$ ( $45 \mathrm{~min}$ before stimulation, followed by $10 \mathrm{~min}$ during stimulation), and the needle was left in place for 5 min before withdrawal. Then the animals were perfused with 4\% PFA as described below. Sham-injected rats were treated identically except that the glass micropipette contained only the vehicle diluted in $0.9 \% \mathrm{NaCl}$.

\section{RESULTS}

\section{Kinetics of ERK activation and IEG transcriptional regulation on corticostriatal pathway stimulation}

The activation of ERK proteins, detected with an antiserum specifically recognizing their phosphorylated form (anti-phospho$\mathrm{Thr}^{183}$ and $-\mathrm{Tyr}^{185}$ ), was not observed in the striatum of shamstimulated rats (Fig. 1A). Similarly, although there was a clear activation in the implanted cerebral cortex, neither c-fos nor zif 268 mRNAs, detected by in situ hybridization, were upregulated in the striatum of these rats (Fig. $1 D, G$ ). A short-term electrical stimulation (15 min) applied unilaterally in the motor cortex induced intense P-ERK immunostaining (Fig. $1 B$ ) precisely in the projection area of stimulated cortical neurons: the lateral striatum (Sgambato et al., 1997). The bilaterality of the corticostriatal afferents (McGeorge and Faull, 1987) was reflected by a bilateral induction of P-ERK immunoreactivity in the lateral striatum. The upregulation of c-fos and zif 268 mRNAs, detected on adjacent brain sections, was spatiotemporally coincident with P-ERK induction at this time point (compare Fig. $1 B$ with $E$ and $H$ ). Remarkably, after long-term stimulation (60 min) P-ERK immunoreactivity clearly was reduced bilaterally in the lateral striatum (Fig. 1C). This reduction contrasted with the sustained induction of both messengers in these striatal areas (Fig. 1F,I).

To determine the kinetics of ERK activation, we measured P-ERK immunoreactivity after 15, 30, 45, and $60 \mathrm{~min}$ of stimulation (Fig. 2A). In the medial striatum, corresponding to the nonactivated area, P-ERK immunostaining did not vary regardless of the stimulation duration that was used. In the lateral striatum, the activated projection area, the immunoreactive signal was significantly higher than in the medial striatum after 15, 30, and 45 min of stimulation. However P-ERK induction was transient. The maximal signal was found at $15 \mathrm{~min}$; it then slowly declined from 30 to $45 \mathrm{~min}$ and returned to basal levels at $60 \mathrm{~min}$. Contrasting with the transient P-ERK induction, c-fos and zif 268 mRNA levels increased progressively between 15 and $30 \mathrm{~min}$, reached maximal levels at $30 \mathrm{~min}$, and then remained stable (Fig. $2 B, C)$. In the medial part of the striatum, regardless of the stimulation duration that was used, no hybridization signals were
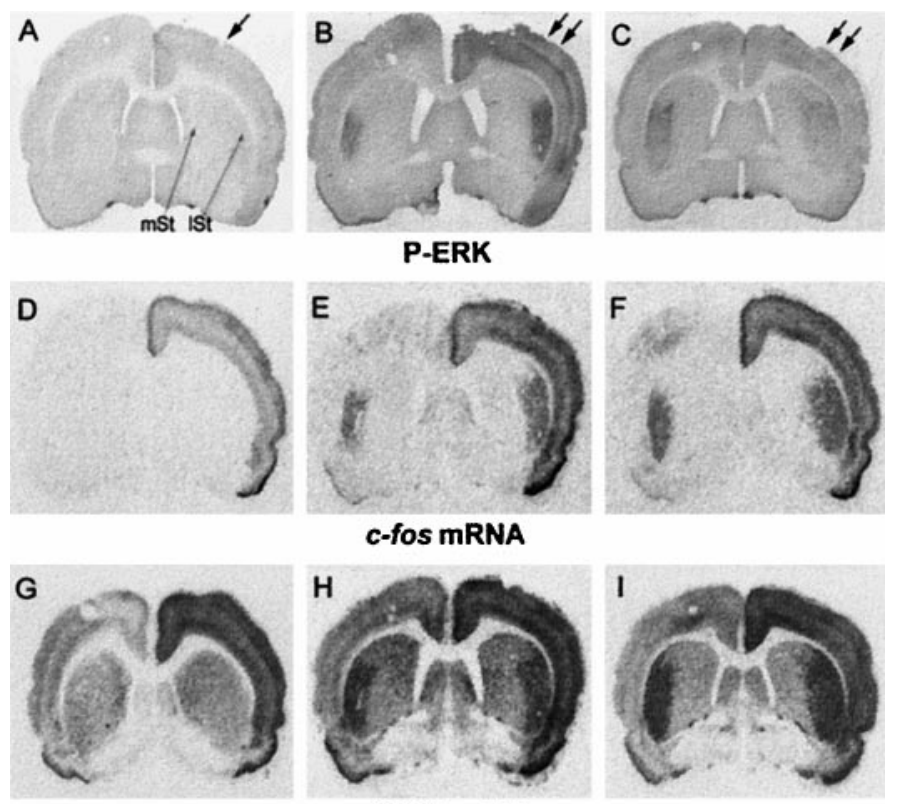

c-fos mRNA
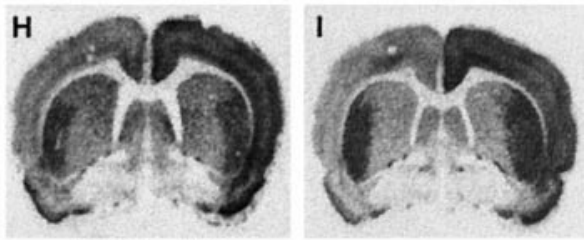

zif 268 mRNA

Figure 1. ERK activation occurs in a tight spatial register with c-fos and zif 268 mRNA induction after unilateral stimulation of the corticostriatal pathway. Brain sections were processed for P-ERK immunoreactivity $(A-C)$ and in situ hybridization of c-fos $(D-F)$ and zif $268(G-I)$ mRNAs. Sham-stimulated rats (sham; $A, D, G$ ) were electrode-implanted in the right cerebral cortex (arrow in $A$ ). Although P-ERK immunostaining $(A)$ is not detectable, c-fos $(D)$ and zif $268(G)$ mRNAs are induced slightly in the implanted cortex, with no apparent upregulated signal in the striatum of sham-stimulated rats. Stimulated rats were electrodeimplanted in the right cerebral cortex and received electrical cortical stimulation (double arrows in $B, C$ ) for either $15 \mathrm{~min}\left(15^{\prime}\right.$ stim; $\left.B, E, H\right)$ or $60 \mathrm{~min}\left(60^{\prime} \mathrm{stim} ; C, F, I\right)$. At $15 \mathrm{~min}$ of stimulation a strong activation of P-ERK $(B)$ occurred bilaterally in the lateral striatum $(l S t)$, but not in the medial striatum $(m S t)$. Note that this activation occurs in a spatial register with both c-fos $(E)$ and zif $268(H)$ mRNA induction. At $60 \mathrm{~min}$ of cortical stimulation, although ERK activation $(C)$ decreased in the lateral striatum, c-fos $(F)$ and zif 268 (I) mRNAs remained strongly induced bilaterally.

detectable for c-fos mRNA, and the constitutive levels of zif 268 mRNA did not vary (Fig. $2 B, C$ ).

The progressive dephosphorylation of ERK proteins observed in the activated lateral striatum suggested a possible negative feedback regulation arising from a specific phosphatase. MKP-1 is described in vitro on cell line models as an IEG for which the rapid transcription by mitogens and subsequent translation are suggestive of a feedback loop mechanism providing a rapid inactivation of ERK (Charles et al., 1993; Sun et al., 1993). We thus tested whether MKP-1 mRNA could be upregulated in vivo in our model. In sham-stimulated rats, although MKP-1 mRNAs were induced in the implanted cortex, no signal was detectable in both striata (Fig. $3 A$ ). At 15 min of stimulation, MKP-1 mRNAs were induced bilaterally and specifically in the lateral striatum, matching the spatial ordering of ERK activation (compare Figs. $3 B$ and $1 B$ ). By increasing the stimulation from 15 to $60 \mathrm{~min}$, MKP-1 mRNA induction was enhanced further in the lateral striatum, whereas levels of this mRNA remained low in the medial part of the striatum (Fig. 3D). At 60 min, a strong MKP-1 mRNA induction occurred in a tight spatial register with the slight ERK activation (compare Figs. $3 C$ and $1 C$ ). Thus, corticostriatal pathway stimulation leads to a rapid and sustained induction of MKP-1 mRNA, which is likely to account for a negative 
A

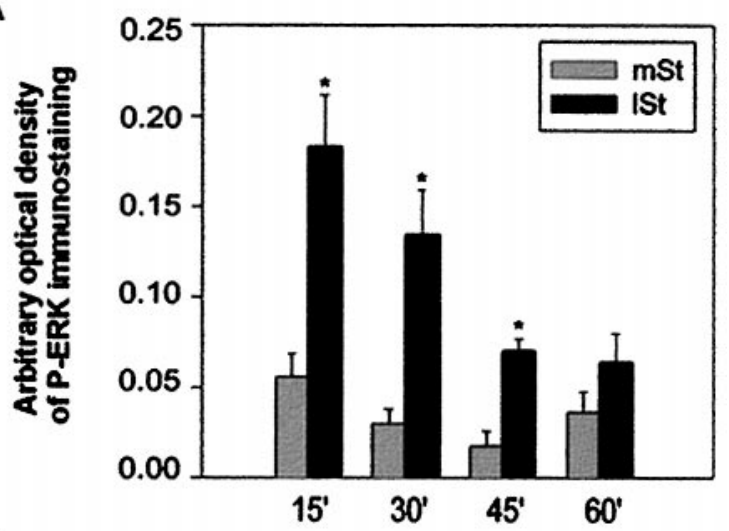

B

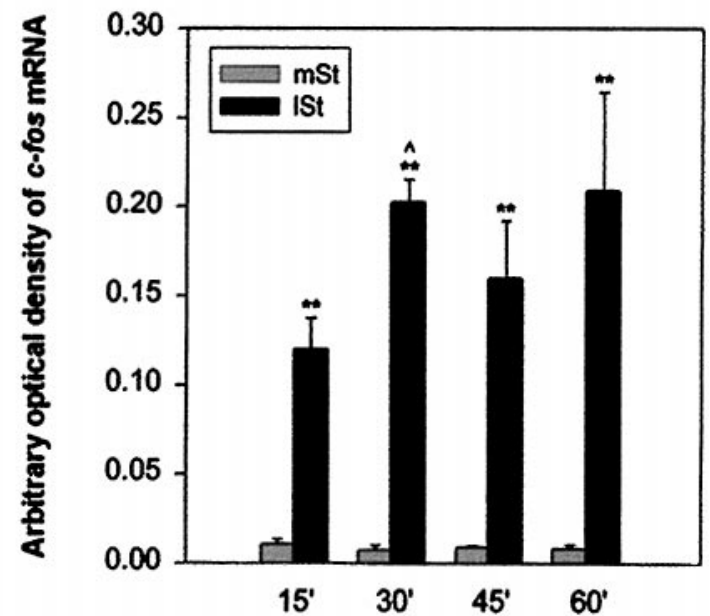

C

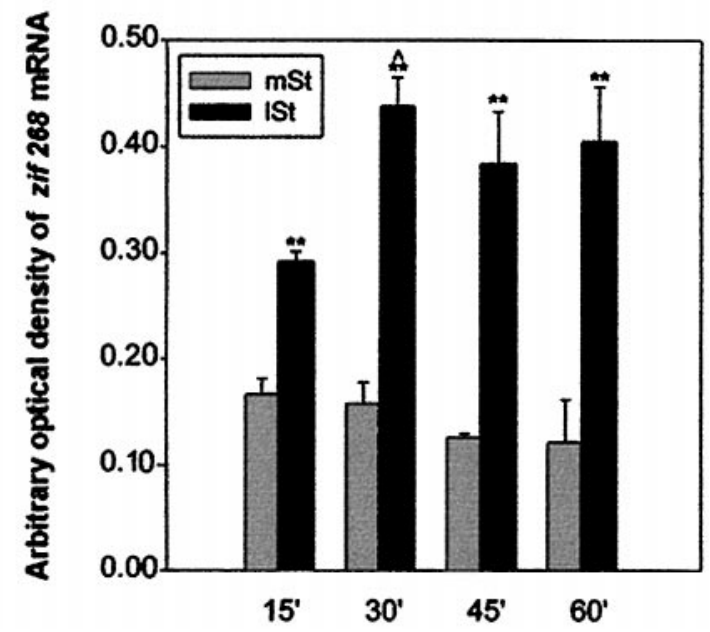

Figure 2. Kinetics of ERK activation and c-fos and zif 268 transcriptional regulation on corticostriatal stimulation. Statistical comparisons were performed from three independent animals for each time point, using an image analyzer (IMSTAR, Paris, France). $A$, Densitometric measurements of P-ERK immunostaining. Signals were significantly higher in the lateral striatum $(l S t)$ than in the medial striatum $(m S t)$ after 15,30 , and 45 min of stimulation ( ${ }^{*} p<0.05$, paired Student's $t$ test), but not at $60 \mathrm{~min}$. P-ERK immunoreactivity was maximal at $15 \mathrm{~min}$ and then progressively decreased to return to basal levels. $B, C$, Autoradiographic signals from c-fos $(B)$ and zif $268(C)$ mRNA detection. Both mRNA levels were significantly higher in the $l S t$ than in the $m S t$, regardless of the stimulation period used $\left({ }^{*} p<0.01\right.$, paired Student's $t$ test). Moreover, messenger levels were significantly higher at 30 than at 15 min of stimulation $(p<$ 0.05 , unpaired Student's $t$ test) and then remained high. Note that the transient activation of ERK correlated with a sustained transcriptional regulation of both messengers.
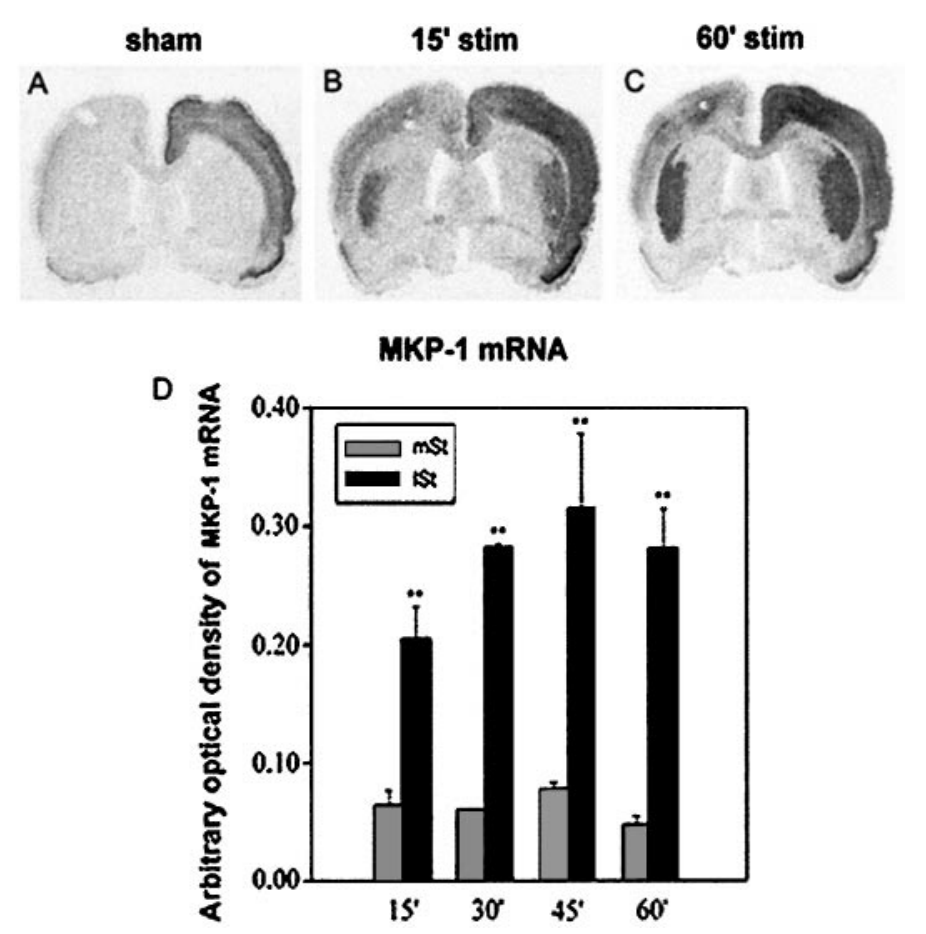

Figure 3. MKP-1 mRNA induction on corticostriatal stimulation. Brain sections of sham-stimulated and stimulated rats were processed for in situ hybridization of MKP-1 mRNAs $(A-C)$. In sham-stimulated rats $(A)$ MKP-1 mRNA levels were detected in the implanted cortex, with no apparent signal in the striatum. By contrast, at $15 \mathrm{~min}$ of stimulation $(B)$, although no signals were detected in the medial striatum, MKP-1 mRNA was strongly induced bilaterally in the lateral striatum. This induction persisted at $60 \mathrm{~min}$ of stimulation $(C)$. Note that MKP-1 induction spatiotemporally correlated with the ERK activation and IEG induction shown in Figure 1. $B$, Statistical comparisons were performed from three independent animals with an image analyzer (IMSTAR) after densitometric measurements of mRNA signals on autoradiograms. MKP-1 mRNA levels were significantly higher in the lateral striatum $(l S t)$ than in the medial striatum $(\mathrm{mSt})$, regardless of the stimulation period used (** $p<0.01$, paired Student's $t$ test).

feedback loop underlying ERK dephosphorylation after 45 and 60 min of stimulation.

\section{Coincident activation of ERK, Elk-1, and CREB on corticostriatal stimulation}

On cell lines after serum activation, ERK phosphorylation leads to SRE-driven gene regulation via the hyperphosphorylation of Elk-1 (Hill et al., 1993; Marais et al., 1993; Zinck et al., 1993; Hipskind et al., 1994a,b; Janknecht et al., 1994). Recent evidence also indicates that, in neurotrophin-activated PC12 cells or primary cortical neurons, CREB is targeted by ribosomal protein S6 kinase (RSK) (Xing et al., 1996; Finkbeiner et al., 1997), a substrate of ERK proteins (Strugill et al., 1988) (for review, see Seger and Krebs, 1995). We thus searched to trace whether ERK activation, observed at $15 \mathrm{~min}$, was associated with Elk-1 and/or CREB hyperphosphorylation. For this purpose we used antiactive Elk-1 (anti-phospho-Ser ${ }^{383}$ ) and CREB (anti-phosphoSer $^{133}$ ) antibodies, together with the anti-active ERK antibody. Immunocytochemical detection of these antibodies was analyzed on sections adjacent to those used for P-ERK and IEG mRNA detection in sham and 15-min-stimulated rats. In sham animals, although P-ERK immunoreactivity was undetectable in the whole striatum (Fig. 4A,B), low constitutive labeling was detectable in the nuclei for P-Elk-1 (Fig. 4E,F) and P-CREB (Fig. 4I,J). In the 


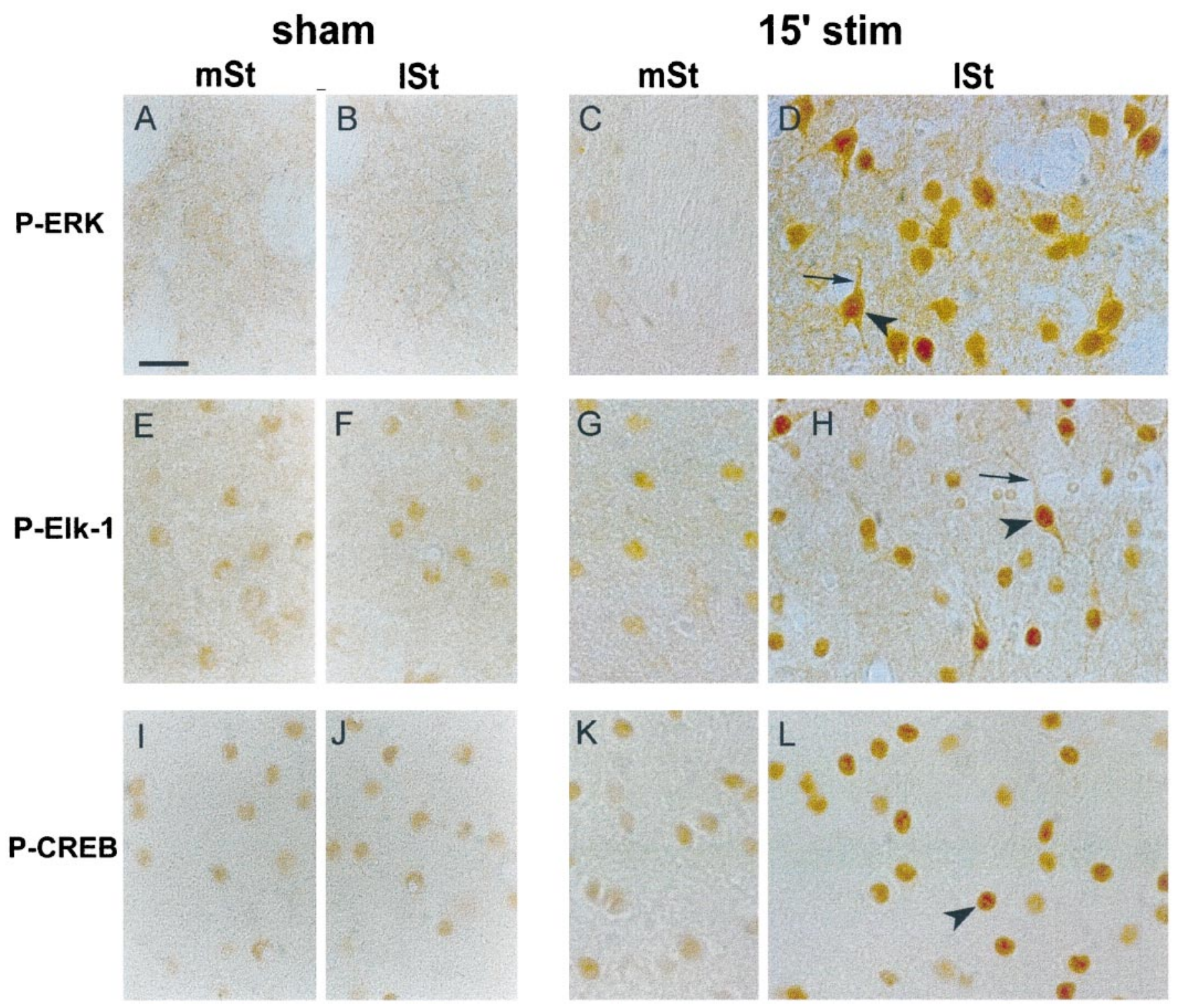

Figure 4. Hyperphosphorylation of ERK, Elk-1, and CREB after 15 min of corticostriatal stimulation. Adjacent brain sections of sham (left panels) or 15-min-stimulated (15' stim; right panels) rats were processed in parallel for P-ERK $(A-D)$, P-Elk-1 $(E-H)$, and P-CREB $(I-L)$ immunohistochemistry. In the medial striatum $(m S t)$ and lateral striatum $(l S t)$ of sham animals, although no constitutive expression of P-ERK was detectable $(A, B)$, a slight constitutive nuclear expression was visible for P-Elk-1 $(E, F)$ and P-CREB $(I, J)$. In the $m S t$ of $15^{\prime}$-stimulated rats, immunolabeling for P-ERK $(C)$, P-Elk-1 $(G)$, and P-CREB $(K)$ was similar to that in sham. By contrast, a clear increase of P-ERK $(D)$, P-Elk-1 $(H)$, and P-CREB $(L)$ was detectable in the $l S t$. The activation of ERK $(D)$ occurred in both nuclear (arrowhead) and cytoplasmic (thin arrow) neuronal compartments. Similarly, Elk-1 hyperphosphorylation $(H)$ occurred in the nucleus (arrowhead) as well as in cytoplasmic compartments $($ thin arrow). Finally, CREB activation $(L)$ was restricted to the nucleus (arrowhead) of striatal cells. Data are representative of three independent rats for each group. Scale bar, $1 \mathrm{~cm}=15 \mu \mathrm{m}$.

medial striatum of stimulated rats, P-ERK (Fig. 4C), P-Elk-1 (Fig. $4 G$ ), and P-CREB (Fig. $4 K$ ) showed the same pattern of immunoreactivity as in sham animals. Thus, phosphorylation events were not influenced by the surgery and electrode manipulation.

By contrast, in the lateral striatum of 15-min-stimulated rats, immunostaining for P-ERK (Fig. 4D), P-Elk-1 (Fig. 4H), and P-CREB (Fig. 4L) was increased markedly, in a tight correspondence with IEG induction (data not shown). In this striatal part the P-ERK-positive neurons showed immunostaining in cytoplasmic compartments (including the dendrites; Fig. 4D, thin arrow) suggestive of a local activation of the protein. Moreover, the appearance of strong nuclear staining (Fig. 4D, arrowhead) was in favor of a nuclear translocation of activated ERK proteins.
P-Elk-1 immunostaining was increased markedly in nuclei (Fig. $4 H$, arrowhead) but also in cytoplasmic (soma and dendrites; Fig. $4 H$, thin arrow) compartments of activated striatal neurons. Thus, in postsynaptic striatal cells, Elk-1 hyperphosphorylation occurred not only in the nucleus, where it can activate the SREDNA regulatory element of IEG promoters, but also in the cytoplasm. By contrast, CREB hyperphosphorylation was observed exclusively in cell nuclei (Fig. 4L, arrowhead), a result in full agreement with previous studies showing its strictly nuclear localization and regulation (Yamamoto et al., 1989).

To confirm biochemically the specificity of anti-active antibodies used in immunocytochemistry, we performed Western blots on extracts prepared from striata of stimulated rats (Fig. $5 A-C$ ). 


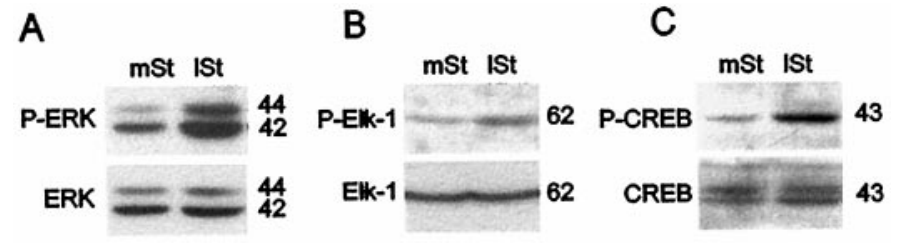

Figure 5. Western blot analysis of P-ERK, P-Elk-1, and P-CREB immunoreactivity in medial and lateral parts of the striatum after $15 \mathrm{~min}$ of stimulation. Extracts of medial $(\mathrm{mSt})$ and lateral $(\mathrm{lSt})$ striatum were dissected rapidly and processed for Western blots. Detection of antiactive proteins was analyzed first, and then total proteins were visualized on the same blot after a stripping procedure. Note the increase of P-ERK $(A)$, P-Elk-1 $(B)$, and P-CREB $(C)$ immunoreactivities in the $l S t$ when compared with the $m S t$ and the same level of total ERKs $(A)$, Elk-1 $(B)$, and CREB $(C)$ proteins in both striatal regions. Molecular weights (in $\mathrm{kDa})$ are indicated to the right of each blot.

P-ERK antibody yielded two bands of 42 and $44 \mathrm{kDa}$, the expected sizes for ERKs 1 and 2 (Fig. 5A). The P-ERK immunoreactivity clearly was increased in extracts from the lateral striatum relative to those from the medial striatum. This increase reflected ERK activation, because comparable levels of ERKs 1 and 2 were present in both extracts (Fig. 5A). Similarly, the P-Elk-1 antibody, which yielded one band of $62 \mathrm{kDa}$, the expected size for Elk-1, gave increased signals in extracts from the lateral striatum relative to those from the medial striatum, whereas comparable levels of total Elk-1 were present in both extracts (Fig. 5B). With P-CREB antibody, a $43 \mathrm{kDa}$ band also was induced specifically in extracts from the lateral striatum when compared with those relative to the medial striatum (Fig. $5 C$ ), whereas levels of nonphosphorylated CREB proteins (corresponding to $43 \mathrm{kDa}$ molecular weight) were similar in both extracts.

\section{Long-term stimulation leads to a dephosphorylation of ERK, Elk-1, and CREB}

A comparative analysis of P-ERK-, P-Elk-1-, and P-CREBpositive cells was performed after various stimulation time points. We observed a significant decrease in the number of P-ERKpositive neurons between 30 and $45 \mathrm{~min}$ and at $60 \mathrm{~min}$ (Fig. 6A). At this time point only a few neuronal cells remained labeled for P-ERK in the lateral striatum (Fig. 6C). In these cells P-ERK was still detectable in cytoplasmic (Fig. 6C, thin arrow) and nuclear (Fig. 6C, arrowhead) compartments. For P-Elk-1 and P-CREB, only cells presenting hyperphosphorylation were counted in this area. This showed a significant decrease between 15 and 30 min, which continuously declined thereafter to reach very low values at 60 min (Fig. 6A). At this time point very few P-Elk-1 cells were detectable in the lateral striatum (Fig. $6 E$ ). These latter cells were large neurons with a strong immunoreactive nucleus (Fig. 6E, arrowhead) and long immunostained proximal dendrites (Fig. 6E, thin arrow). Similarly, P-CREB immunocytochemistry was decreased markedly in the lateral striatum at $60 \mathrm{~min}$ of stimulation (Fig. 6G). Some scarce neurons also showed strong nuclear immunolabeling (Fig. 6G, arrowhead). Noteworthy, even the constitutive immunostaining of P-Elk-1 and P-CREB observed in the medial striatum (Fig. 6D,F) was no longer detectable in the lateral striatum after $60 \mathrm{~min}$ of stimulation.

Thus, after long-term stimulation the drastic decrease of P-Elk-1 and P-CREB immunoreactivity contrasted with a slighter decrease of P-ERK. These data suggest that the dephosphorylation of these transcription factors was not fully coupled with ERK inactivation.

\section{Parke Davis 98059, an inhibitor of ERK activation, abolishes cortically driven IEG induction in the striatum}

At 15 min, P-ERK was correlated spatially with the onset of IEG induction, a result strongly suggesting a relationship between these events. To go further in the role of the ERK pathway in IEG induction, we analyzed the role of PD 98059, a specific MEK-1 and MEK-2 inhibitor with $\mathrm{IC}_{50}$ values of 10 and $50 \mu \mathrm{M}$, respectively (Pang et al., 1995). The specificity of PD 98059 for MEK-1 and MEK-2 has been demonstrated in experiments in which PD 98059 failed to inhibit the activity of 18 other Ser/Thr kinases (Alessi et al., 1995; Dudley et al., 1995). We injected PD 98059 at $100 \mu \mathrm{M}$ stereotaxically in the lateral striatum. This injection was performed unilaterally (ipsilaterally to the stimulation) 45 min before and during the 15 min stimulation. We chose this stimulation period because ERK activation was maximal at this time point (Fig. 6A).

Although the unilateral injection of vehicle did not affect striatal ERK activation (Fig. 7B), cortically driven P-ERK induction was abolished completely after PD 98059 injection in the injected striatum (Fig. 7D, asterisk), and not contralaterally (Fig. 7C). Total ERK proteins remained unchanged after PD 98059 injection (Fig. 7H), thus demonstrating that PD 98059 affects ERK activation, and not ERK protein levels. Counterstaining by cresyl violet revealed the integrity of neuronal cells in both striata (data not shown).

We then analyzed, on sections adjacent to those used above, IEG mRNA induction. In vehicle-injected rats the stimulation induced a striatal bilateral induction of c-fos (Fig. 7I), zif 268 (Fig. $7 K$ ), and MKP-1 (Fig. 7M) mRNAs. By contrast, in PD 98059injected rats a complete inhibition of c-fos (Fig. 7J), zif 268 (Fig. $7 L$ ), and MKP-1 (Fig. 7N) mRNA induction was observed in the injected striatum (Fig. 7, asterisk), in register with the prevention of ERK activation. Cortically driven ERK activation and IEG induction were still detected in the contralateral striatum to PD 98059 injection, thus demonstrating the efficacy of the cortical stimulation. In some experiments in which a smaller PD 98059 volume was tested, we obtained a limited inhibition of c-fos and zif 268 mRNAs in a spatial register with the blockade of ERK activation (data not shown). Together, these results indicate that IEG induction strictly depends on the ERK cascade activation.

\section{ERK proteins dually control Elk-1 and CREB hyperphosphorylation}

The hyperphosphorylation of Elk-1 and CREB appeared in the lateral striatum at $15 \mathrm{~min}$ of stimulation, i.e., concomitantly to ERK activation and in a strict spatial correspondence with IEG induction. We thus addressed a possible role of the ERK cascade activation in the regulation of these transcription factors. For this purpose, anti-active Elk-1 (Fig. 8E-H) and CREB (Fig. 8I-L) immunostaining were performed, after PD 98059 injection, on sections adjacent to those processed for P-ERK labeling (Fig. $8 A-D)$. In the PD 98059-injected striatum, P-Elk-1 immunoreactivity was no longer increased (compare Fig. 8, $H$ with $G$ ), thus indicating its downregulation after the ERK blockade. On the contralateral side to PD 98059 injection, P-Elk-1 immunoreactivity remained increased in the lateral striatum (compare Fig. 8, E with $F$ ). These results indicate that Elk-1 hyperphosphorylation depends strictly on the ERK cascade activation.

More surprisingly, we also observed an abolition of P-CREB increase after PD 98059 injection (compare Fig. 8, L with $K$ ). This was not the case in the contralateral side, where a strong 

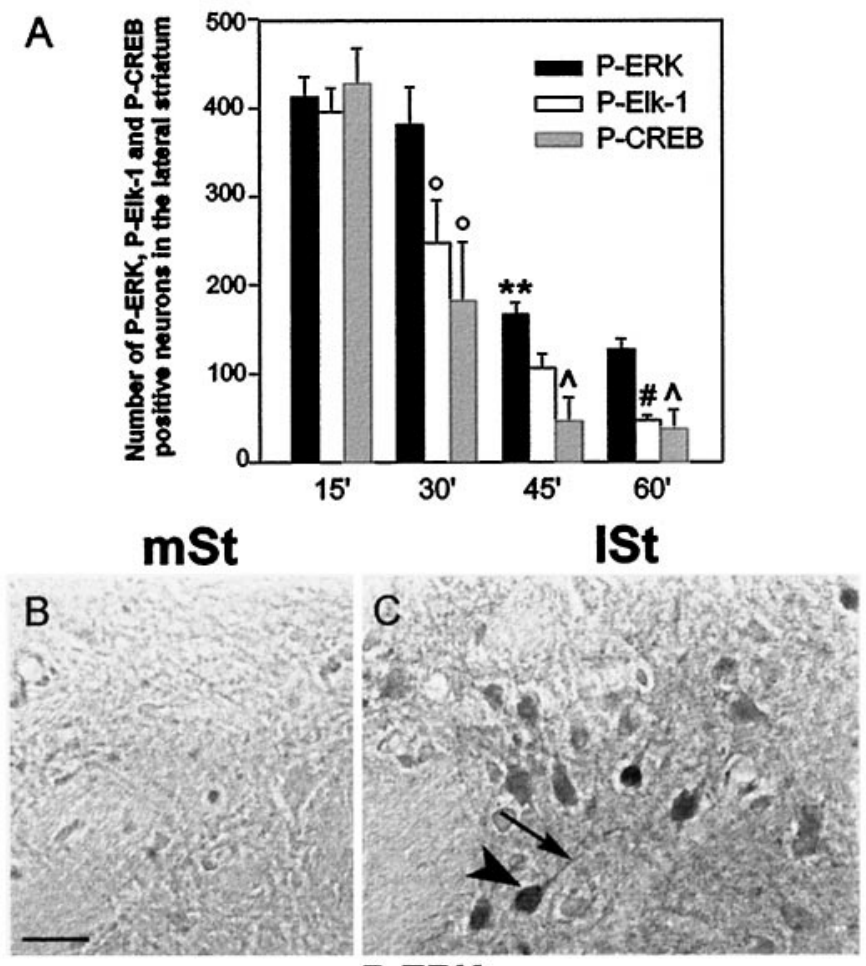

P-ERK

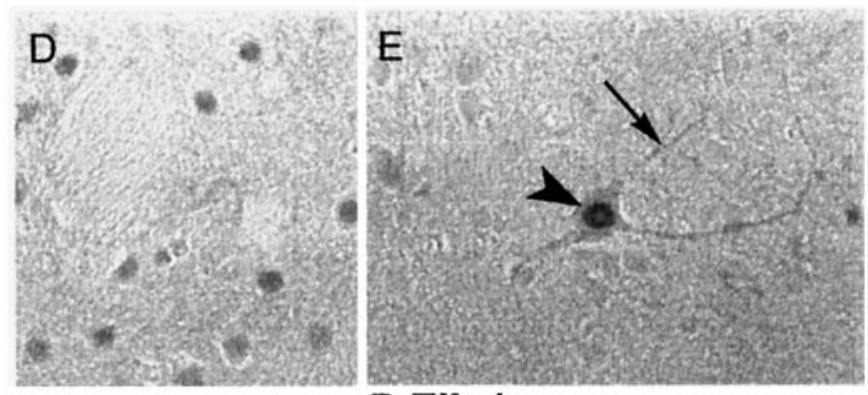

\section{P-Elk-1}

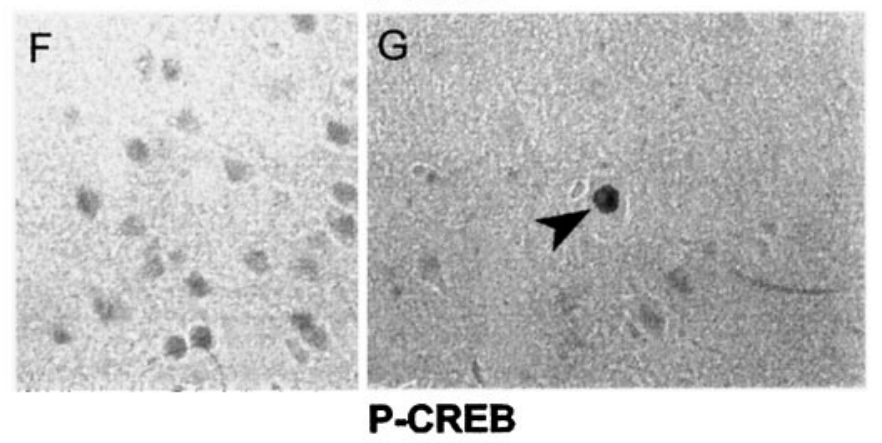

Figure 6. Inactivation of ERK, Elk-1, and CREB after 60 min of corticostriatal stimulation. $A$, Quantification of P-ERK, P-Elk-1, and P-CREB immunoreactive striatal cells at $15,30,45$, and $60 \mathrm{~min}$ of corticostriatal stimulation ( $n=3$ rats for each stimulation period). Cells counts were performed with an image analyzer (Biocom) in the lateral striatum ipsilaterally to the stimulation (total surface area examined, $2.7 \mathrm{~mm}^{2}$ ). Statistical comparisons were performed with a one-way ANOVA. ${ }^{* *} p<$ 0.01 when comparing P-ERK immunostaining between 45 and $30 \mathrm{~min}$; ${ }^{\circ} p<0.05$ when comparing P-Elk- 1 and P-CREB immunostaining between 15 and 30 min; $p<0.05$ when comparing P-CREB with P-ERK at 45 and $60 \mathrm{~min} ; \# p<0.05$ when comparing P-Elk-1 with P-ERK at $60 \mathrm{~min}$. Adjacent brain sections of 60 -min-stimulated rats were processed in parallel for P-ERK $(B, C)$, P-Elk-1 $(D, E)$, and P-CREB $(F, G)$ immunohistochemistry. In the lateral striatum $(l S t)$ few P-ERK immunoreactive hyperphosphorylation of CREB was still detectable in the lateral striatum (compare Fig. 8, $I$ with $J$ ). Thus CREB hyperphosphorylation also depends on the ERK cascade activation in our model.

\section{DISCUSSION}

Three central findings emerge from this in vivo study. First, a transient activation of the ERK signaling pathway is crucial for cortically driven IEG induction. Second, both Elk-1 and CREB transcription factors are targeted by this signaling pathway. This is, to our knowledge, the first demonstration of a dual role of ERK proteins in CRE- and SRE-driven transcriptional regulation in the adult CNS. Third, although CREB activation is strictly nuclear, Elk-1 hyperphosphorylation occurs in both cytoplasmic and nuclear compartments of striatal neurons.

\section{Cortically driven IEG induction is controlled by ERK proteins}

From in vitro models that use the transiently transfected c-fos reporter gene, we know that ERK-mediated gene regulation depends on cell lines and mode of calcium entry (Miranti et al., 1995; Xia et al., 1996; Johnson et al., 1997). To address the involvement of ERK in gene regulation in vivo, we used electrical stimulation of the glutamatergic corticostriatal pathway that leads to a topographical induction of IEGs in the striatum (Sgambato et al., 1997, 1998). The strict spatiotemporal coincidence between ERK activation and the onset of messenger induction suggested that this signaling pathway is required for cortically driven gene regulation. This was confirmed after intrastriatal injection of the MEK inhibitor PD 98059, which completely abolished c-fos and zif 268 as well as MKP-1 mRNA upregulation. Analysis of the transcription factors Elk-1 and CREB allowed us to better understand how ERK proteins controlled the expression of these genes.

\section{ERK dually controls Elk-1 and CREB hyperphosphorylation}

We traced intracellular events linking ERK activation to gene regulation and found a hyperphosphorylation of Elk-1 and CREB in a strict spatial register with P-ERK and IEG mRNA induction. The critical role played by ERK in the activation of these transcription factors was demonstrated after PD 98059 injection. This treatment impaired Elk-1 hyperphosphorylation, a result in agreement with its being a target of ERK. Although the activation of the SRF was not measured in our study, our data suggest that the ERK/Elk-1 module played a necessary and sufficient role in the activation of SRE sites located in the promoter of both c-fos and zif 268.

Calcium-induced CREB phosphorylation classically depends on CaMKs (Sheng et al., 1990) or PKA (Impey et al., 1996). In the latter case a calcium/calmodulin-sensitive adenylyl cyclase

$\leftarrow$

cells were found $(C)$ when compared with those in Figure $4 D$. These cells presented both nuclear (arrowhead) and cytoplasmic (thin arrow) staining. $E$, Very few large neurons remained immunolabeled for P-Elk-1 in the $l S t$ when compared with those in Figure $4 H$. Here again, the labeling was detectable in the nucleus (arrowhead) as well as in the cytoplasmic compartments (thin arrow). Similarly, CREB hyperphosphorylation $(G)$ occurred in the nucleus of very few cells (arrowhead). Note that the constitutive immunolabeling observed in the medial striatum $(\mathrm{mSt})$ for P-Elk-1 $(D)$ and P-CREB $(F)$ is no longer detectable in the $l S t(E$ and $G$, respectively). Data are representative of three independent 60-minstimulated rats. Scale bar, $1 \mathrm{~cm}=15 \mu \mathrm{m}$. 


\section{contra}

$$
\begin{gathered}
\text { ipsi } \\
\text { (vehicle) }
\end{gathered}
$$
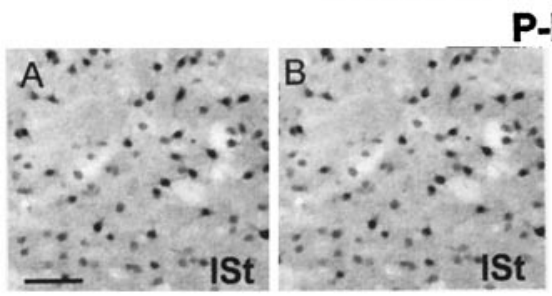

P-ERK
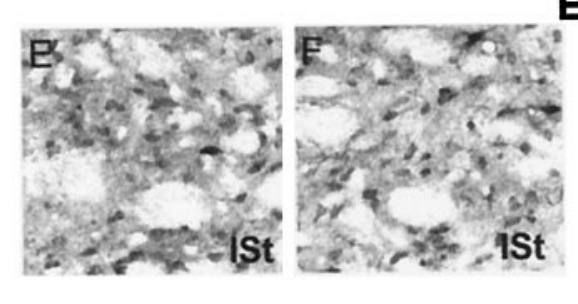

\section{ERK}
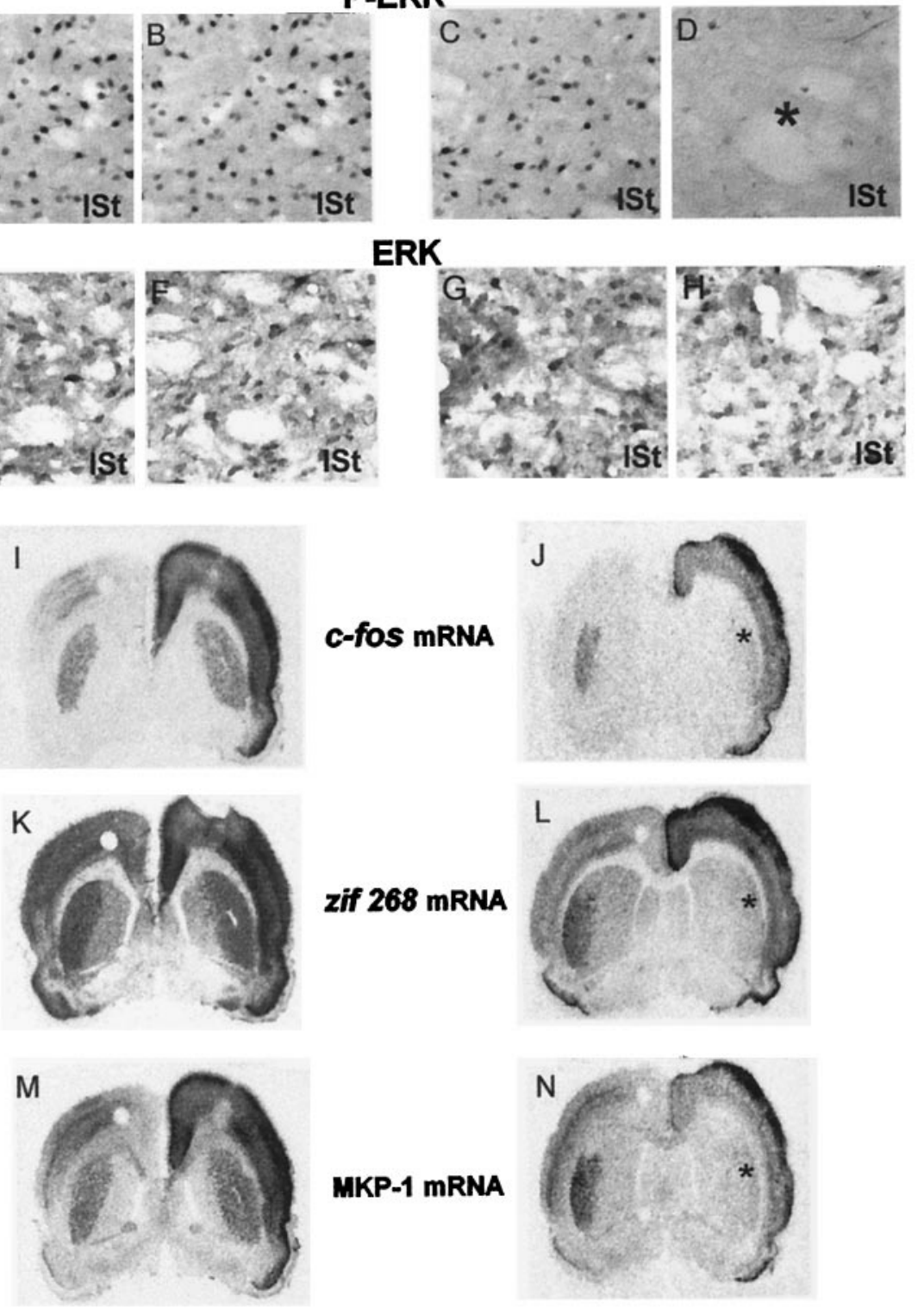

contra

\section{ipsi (PD 98059)}

ISt

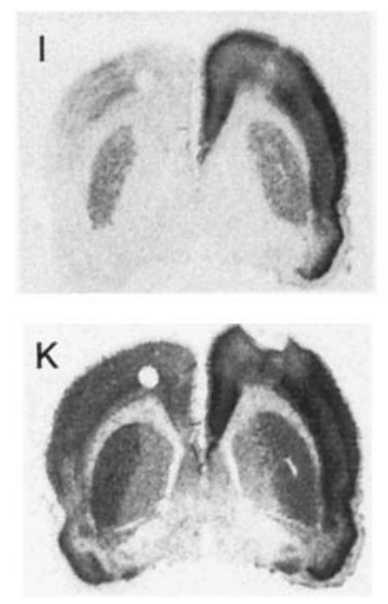

zif $268 \mathrm{mRNA}$

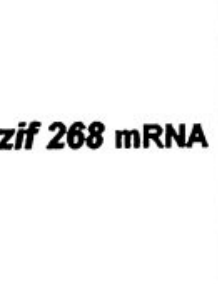

MKP-1 mRNA

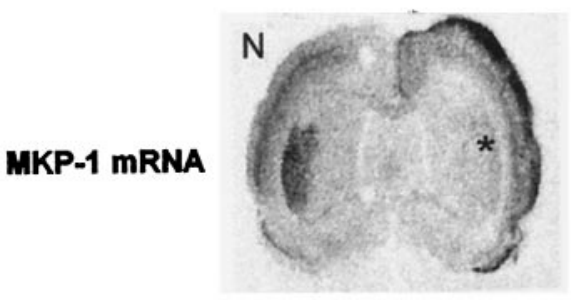

Figure 7. Parke Davis 98059 abolishes IEG induction after 15 min of corticostriatal stimulation. The MEK inhibitor PD 98059 (right columns) or the vehicle (left columns) was injected in the lateral striatum $(l S t)$ unilaterally and ipsilaterally to the electrode implantation. After $15 \mathrm{~min}$ of stimulation, brains were processed for P-ERK $(A-D)$ and ERK $(E-H)$ immunoreactivity and in situ hybridization of c-fos $(I, J)$, zif $268(K, L)$, and MKP-1 $(M, N)$ mRNAs. In vehicle-injected rats the stimulation induced a strong bilateral activation of ERK in the $l S t(A, B)$. By contrast, in PD 98059-injected rats this stimulation produced ERK activation contralaterally $(C)$, but not ipsilaterally $(D$; asterisk $)$, to the inhibitor injection site. ERK immunostaining remained unchanged in vehicle-injected $(E, F)$ and PD 98059-injected $(G, H)$ rats. In vehicle-injected rats the cortical stimulation led to a bilateral induction of c-fos $(I)$, zif $268(K)$, and MKP-1 $(M)$ mRNAs. In PD 98059-injected rats, although IEG mRNAs were still induced contralaterally to the inhibitor injection site, an impairment of induction for c- $f o s(J)$ zif $268(L)$, and MKP-1 $(N)$ was observed ipsilaterally (asterisk) to the PD 98059 injection. These data are representative of three independent rats for each group. Scale bar, $1 \mathrm{~cm}=50 \mu \mathrm{m}$. could be stimulated by calcium influx. However, neither CaMK nor PKA seems to be implicated directly in CREB phosphorylation in our model, because the PD 98059 inhibitor completely abolished CREB hyperphosphorylation. Thus, we hypothesize that ERK activation plays a critical role in CREB regulation (results discussed below). This result highlights the interesting hypothesis that genes containing CRE, and not SRE, DNA regulatory elements, like MKP-1 (Noguchi et al., 1993; Kwak et al., 1994), could be regulated by an ERK-dependent pathway. In neurotrophin-treated PC12 cells and primary cortical neurons, CREB is targeted by RSK (Xing et al., 1996; Finkbeiner et al., 1997), a substrate of ERK proteins (Strugill et al., 1988). Thus we might propose that the ERK-dependent CREB activation implicates RSK as an intermediate in our model. This hypothesis was not tested because of the lack of commercially available antiactive RSK antibodies.

Together, these data show that glutamate-induced IEG induction is dependent on ERK activation targeting both SRE and CRE sites. This is consistent with a study showing that these DNA sequences are essential for the calcium-driven induction of a c-fos reporter gene in transgenic mice (Robertson et al., 1995). In vitro, the phosphorylation of CREB or Elk-1 can recruit the CREB binding protein (CBP) coactivator (Kwok et al., 1994; Janknecht and Nordheim, 1996) to facilitate the assembly of the polymerase II transcription complex at the TATA box that leads to the initiation of transcription. Whether the concomitant activation of CBP by CREB and Elk-1 occurs in vivo remains to be established. However, this could provide the molecular mecha- 


\section{contralateral}
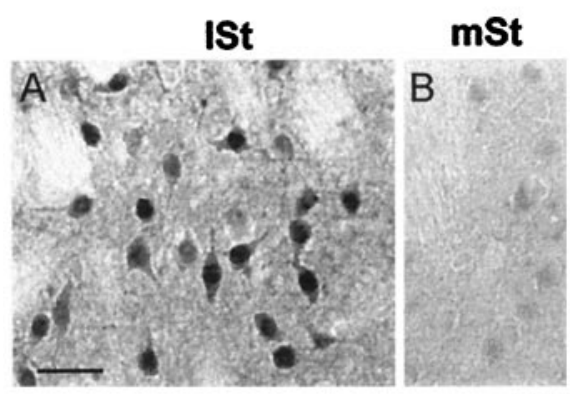

P-ERK
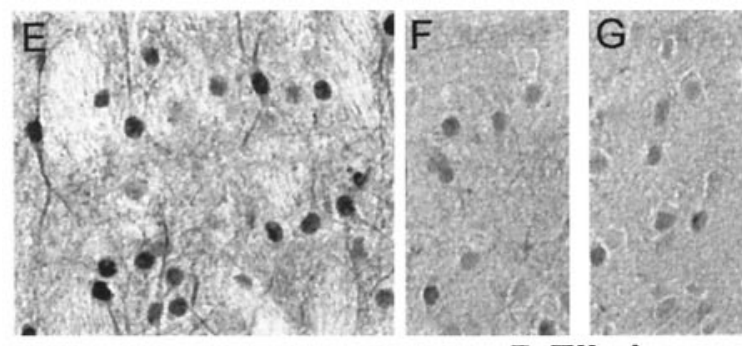

P-Elk-1

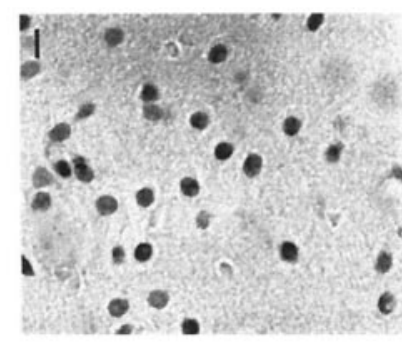

ipsilateral
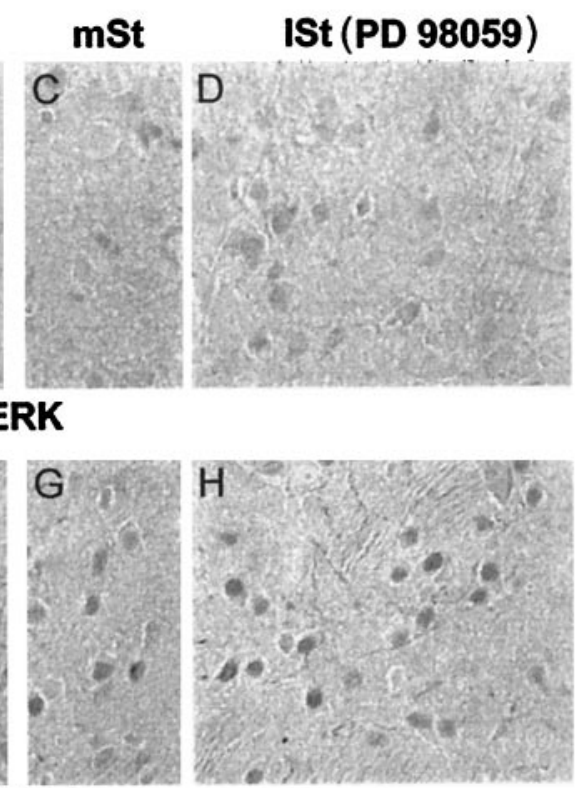

P-ERK $(A-D)$, P-Elk-1 $(E-H)$, and P-CRE $(I-L)$ immunoreactivity. The injection of PD 98059 completely prevented ERK activation in the lateral striatum (lSt) ipsilaterally $(D)$, but not contralaterally $(A)$, to the inhibitor injection site. In the medial striatum $(\mathrm{mSt})$ P-ERK immunoreactivity remained low in both sites $(B, C)$. On sections adjacent to those used below, Elk-1 and CREB hyperphosphorylation were impaired in the $l S t$ ipsilaterally $(H$ and $L$, respectively), but not contralaterally ( $E$ and $I$, respectively), to the PD 98059 injection. The constitutive P-Elk-1 $(F, G)$ and P-CREB $(J, K)$ immunostaining remained low in both medial striata and was comparable to the immunolabeling observed in $l S t$ ipsilaterally to the PD 98059 injection $(H, L)$. Scale bar, $1 \mathrm{~cm}=25 \mu \mathrm{m}$.
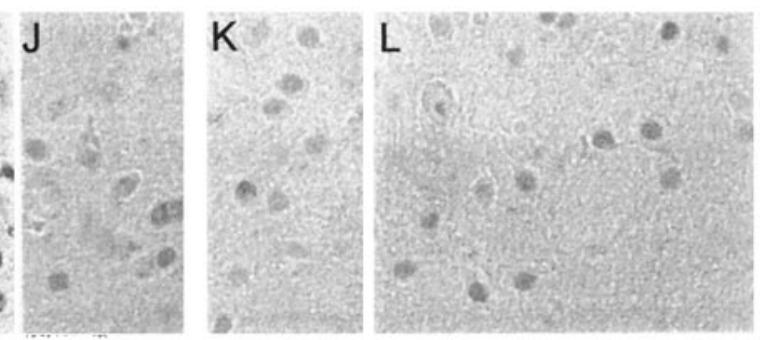

P-CREB nism by which the activation of different DNA regulatory elements can act synergistically to activate IEG transcription.

\section{Persistent IEG induction contrasts with transient activation of both ERK modules}

ERK protein activation was transient in our model. This is consistent with data showing that a transient activation of these proteins is necessary and sufficient to drive LTP in the rat hippocampus (English and Sweatt, 1997). Whether the transient activation of ERK was sufficient to drive long-term gene regulation in our model remains to be established. In that way, considering that both Elk-1 and CREB also were dephosphorylated at this time point, a CaMK-SRF module (Miranti et al., 1995) could relay glutamate-induced gene regulation at late time points.

The strong and early induction of mRNA encoding MKP-1 protein, one of the phosphatases involved in ERK inactivation in transfected cells (Alessi et al., 1993; Sun et al., 1993), was coincident with the progressive ERK inactivation. Although MKP-1 preferentially attenuates signaling via the JNK/SAPK and p38 MAPK pathways (Franklin and Kraft, 1997), its strong induction likely was related to ERK inactivation, because neither JNK/ SAPK nor p38 MAPK was activated after short- or long-term corticostriatal stimulation (data not shown). Additional mechanisms may underlie the drastic dephosphorylation of Elk-1 and CREB, which showed lower levels of phosphorylation than in basal conditions. Calcineurin, a calcium-responsive phosphatase widely expressed in the striatum (Yakel, 1997), is implicated in
CREB dephosphorylation (Bito et al., 1996) and also represents the major Elk-1 serine-threonine phosphatase (Sugimoto et al., 1997). Its role in the dephosphorylation of both transcription factors would be consistent with its being critically involved in LTP (Winder et al., 1998).

\section{Elk-1 and CREB activation occurs in different subcellular compartments}

A striking feature of this work was the visualization of activated proteins in various subcellular compartments, i.e., activation of ERK and Elk-1 in cytoplasmic (dendritic and somatic) and nuclear compartments, and an exclusively nuclear CREB activation. ERK proteins are, in their nonactivated state, enriched in dendritic and somatic compartments (Fiore et al., 1993a; Ortiz et al., 1995). The presence of activated proteins, i.e., phosphorylated, in dendrites suggests a local activation by calcium influx. Corticostriatal afferents impinge precisely on the dendritic spines (Smith and Bolam, 1990) of striatal neurons, on which are localized both AMPA and NMDA glutamatergic receptors (Bernard et al., 1997; V. Bernard and J. P. Bolam, unpublished observations). The NMDA receptors, which may be critically involved in calcium-dependent LTP in the striatum (Charpier and Deniau, 1997), is implicated in striatal Fos induction after cortical stimulation (Abo et al., 1994; Liste et al., 1995). Key intermediate downstream NMDA receptors appear to be the calciumdependent nonreceptor tyrosine kinases, PYK2 or FAK, which in turn can activate the ras-dependent signaling pathway: ras/raf/ 


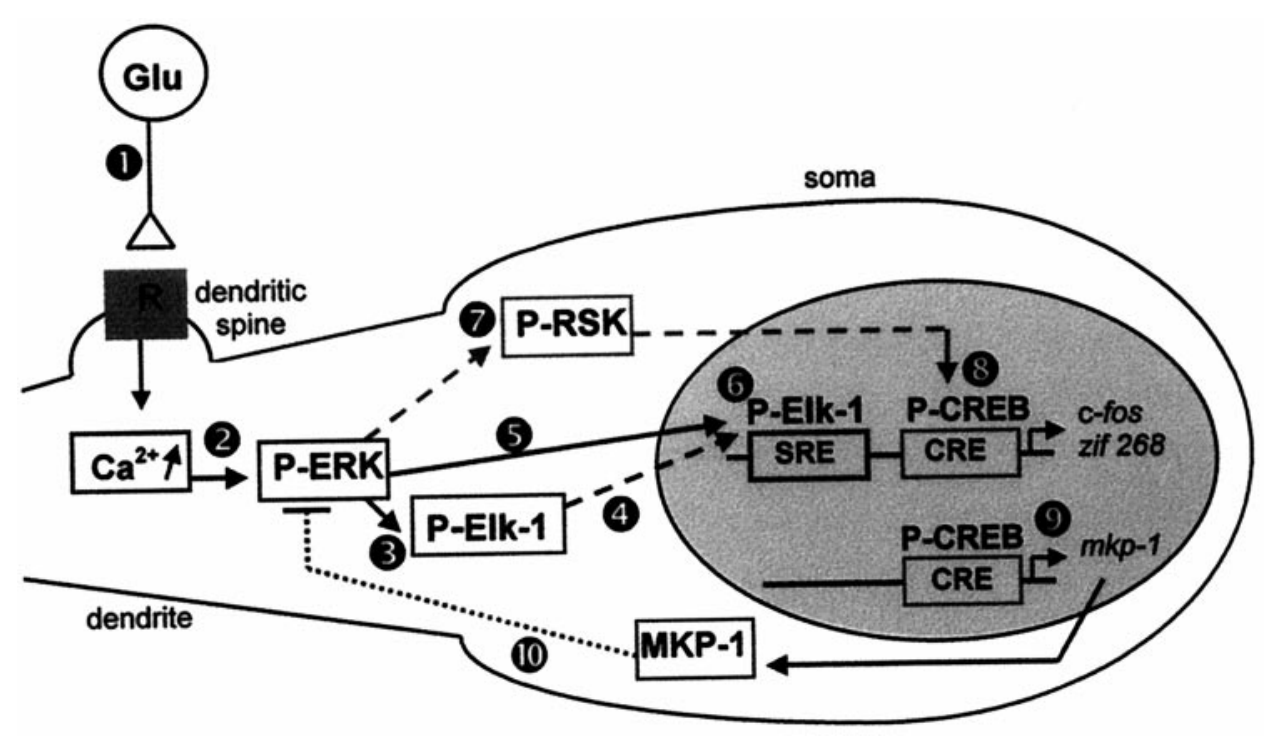

Figure 9. Proposed model for ERKdependent IEG induction on corticostriatal pathway stimulation. Cortical fibers impinge specifically on dendritic spines of striatal neurons (Smith and Bolam, 1990). The electrical stimulation of these afferents leads to glutamate release at corticostriatal synapses (Reubi and Cuenod, 1979), which in turn act via glutamatergic receptors (1). The subsequent and local elevation of intracellular calcium levels, via NMDA receptors, activates ERK machinery (2) located in the dendrites (Fiore et al., 1993a; Ortiz et al., 1995). Elk-1 proteins that are present in dendrites (Sgambato et al., 1998) are phosphorylated locally by ERK proteins (3). Because both ERK and Elk-1 hyperphosphorylated proteins also are found in the nucleus, we suggest that they are translocated into the nucleus on activation $(4,5)$. In the nucleus Elk-1 can mediate the transcriptional regulation of SRE-containing IEGs like c-fos and zif 268 (6). In parallel, we show that activated ERK proteins lead to a hyperphosphorylation of the nuclear CREB protein. The activation of the CREB kinase RSK, a cytoplasmic substrate of ERK proteins (Strugill et al., 1988) (7), and its subsequent translocation into the nucleus (Chen et al., 1992) could explain the ERK-dependent CREB activation in our model. In the nucleus CREB mediates the transcriptional regulation of CRE-containing IEGs like c-fos, zif 268 (8), and MKP-1 (9). The protein MKP-1 may act in a negative feedback loop (10) to downregulate ERK activation. Thus, two different ERK modules are critically involved in IEG induction: ERK/Elk-1/SRE and ERK/?/CREB/CRE.

MEK/ERK (Lev et al., 1995; Siciliano et al., 1996). Interestingly, B-Raf, a member of the raf family, which is enriched in the striatum (Barnier et al., 1995), also is localized in dendrites of striatal neurons.

On cell line models Elk-1 is described as a nuclear transcription factor (Janknecht et al., 1994), which can be phosphorylated locally after the nuclear translocation of activated ERK proteins (Chen et al., 1992). However, in postmitotic neuronal cells Elk-1 is present in its nonactivated state in cytoplasmic and nuclear compartments (Sgambato et al., 1998). The finding of hyperphosphorylated Elk-1 in nuclear compartments after glutamate activation is in agreement with its being a nuclear transcription factor. The presence of activated Elk-1 along with P-ERK in non-nuclear compartments (including the dendrites) indicates that it can be phosphorylated locally, near the calcium entry, by activated ERK proteins. In support of this is the observation that PD 98059 injection abolished the dendritic hyperphosphorylation of Elk-1. Whether Elk-1 then can translocate to the nucleus to trigger gene regulation or play a specific role in the cytoplasm remains to be established; this would be a critical issue in understanding intracellular mechanisms that relay information from the distal dendritic glutamatergic receptors to the nucleus (Fig. 9).

Contrasting with the dual localization of P-Elk-1, activated CREB was exclusively nuclear. This is in agreement with previous data indicating that this transcription factor is a nuclear protein (Yamamoto et al., 1989). Whereas on pituitary cell lines (AtT20) CREB phosphorylation occurs after nuclear translocation of calcium (Hardingham et al., 1997), on hippocampal neurons the increases in nuclear calcium are not sufficient to drive CREB activation (Deisseroth et al., 1996). The mean difference between these cell types is the presence of dendritic processes in hippocampal neurons, and not in AtT20 cells. In other words, when calcium entry occurs far from the soma, and this is precisely the case in striatal neurons, CREB activation can depend on a cytoplasmic kinase. Because (1) ERK machinery is enriched in dendrites and (2) CREB activation is abolished after PD 98059, we suggest that ERK activation is the major event in triggering
CREB hyperphosphorylation in our model. The link between ERK and CREB activation could be the cytoplasmic substrate of ERK, RSK, which in turn could translocate to the nucleus (Chen et al., 1992) to activate CREB (Fig. 9).

In conclusion, our data provide the first in vivo evidence of a strictly ERK-dependent gene regulation by corticostriatal pathway stimulation and bring new insights in intracellular mechanisms underlying LTP in the striatum.

\section{REFERENCES}

Abo V, Deniau JM, Rogard M, Besson MJ (1994) Involvement of the NMDA receptors in the induction of Fos expression in basal ganglia following electrical stimulation of the motor cortex. Eur J Neurosci [suppl] 7:101.

Alessi DR, Smythe C, Keyse SM (1993) The human CL100 gene encodes a Tyr/Thr-protein phosphatase which potently and specifically inactivates MAP kinase and suppresses its activation by oncogenic ras in Xenopus oocyte extracts. Oncogene 8:2015-2020.

Alessi DR, Cuenda A, Cohen P, Dudley DT, Saltiel AR (1995) PD 098059 is a specific inhibitor of the activation of mitogen-activated protein kinase in vitro and in vivo. J Biol Chem 270:27489-27494.

Bading H, Greenberg ME (1991) Stimulation of protein tyrosine phosphorylation by NMDA receptor activation. Science 253:912-914.

Bading H, Ginty DD, Greenberg ME (1993) Regulation of gene expression in hippocampal neurons by distinct signaling pathways. Science 260:181-186.

Barnier JV, Papin C, Eychène A, Lecoq O, Calothy G (1995) The mouse $\mathrm{B}$-raf gene encodes multiple protein isoforms with tissue-specific expression. J Biol Chem 270:23381-23389.

Bernard V, Somogyi P, Bolam JP (1997) Cellular, subcellular, and subsynaptic distribution of AMPA-type glutamate receptor subunits in the neostriatum of the rat. J Neurosci 17:819-833.

Bito H, Deisseroth K, Tsien RW (1996) CREB phosphorylation and dephosphorylation: a $\mathrm{Ca}^{2+}$ - and stimulus duration-dependent switch for hippocampal gene expression. Cell 87:1203-1214.

Boulton TG, Cobb MH (1991) Identification of multiple extracellular signal-regulated kinases (ERKs) with antipeptide antibodies. Cell Regul 2:357-371.

Charles CH, Sun H, Lau LF, Tonks NK (1993) The growth factorinducible immediate-early gene $3 \mathrm{CH} 134$ encodes a protein-tyrosinephosphatase. Proc Natl Acad Sci USA 90:5292-5296.

Charpier S, Deniau JM (1997) In vivo activity-dependent plasticity at 
corticostriatal connections: evidence for physiological long-term potentiation. Proc Natl Acad Sci USA 94:7036-7040.

Chen RH, Sarneki C, Blenis J (1992) Nuclear localization and regulation of erk- and rsk-encoded protein kinases. Mol Cell Biol 12:915-927.

Dash PK, Karl KA, Prywes R, Kandel ER (1991) cAMP response element-binding protein is activated by $\mathrm{Ca}^{2+} /$ calmodulin- as well as cAMP-dependent protein kinase. Proc Natl Acad Sci USA 88:5061-5065.

Deisseroth K, Bito H, Tsien RW (1996) Signaling from synapse to nucleus: postsynaptic CREB phosphorylation during multiple forms of hippocampal synaptic plasticity. Neuron 16:89-101.

Dudley DT, Pang L, Decker SJ, Bridges AJ, Saltiel AR (1995) A synthetic inhibitor of the mitogen-activated protein kinase cascade. Proc Natl Acad Sci USA 92:7686-7689.

English JD, Sweatt JD (1996) Activation of p42 mitogen-activated protein kinase in hippocampal long-term potentiation. J Biol Chem 271:24329-24332.

English JD, Sweatt JD (1997) A requirement for the mitogen-activated protein kinase cascade in hippocampal long-term potentiation. J Biol Chem 272:19103-19106.

Finkbeiner S, Tavazoie SF, Maloratsky A, Jacobs KM, Harris KM, Greenberg ME (1997) CREB: a major mediator of neuronal neurotrophin responses. Neuron 19:1031-1047.

Fiore RS, Bayer VE, Pelech SL, Posada J, Cooper JA, Baraban JM (1993a) p42 mitogen-activated protein kinase in brain: prominent localization in neuronal cell bodies and dendrites. Neuroscience 55:463-472.

Fiore RS, Murphy TH, Sanghera JS, Pelech SL, Baraban JM (1993b) Activation of mitogen-activated protein kinase by glutamate receptor stimulation in rat primary cortical cultures. J Neurochem 61:1626-1633.

Franklin CC, Kraft AS (1997) Conditional expression of the mitogenactivated protein kinase (MAPK) phosphatase MKP-1 preferentially inhibits p38 MAPK and stress-activated protein kinase in U937 cells. J Biol Chem 272:16917-16923.

Ghosh A, Greenberg ME (1995) Calcium signaling in neurons: molecular mechanisms and cellular consequences. Science 268:239-247.

Gille H, Sharrocks AD, Shaw PE (1992) Phosphorylation of transcription factor $\mathrm{p} 62 \mathrm{TCF}$ by MAP kinase stimulates ternary complex formation at c-fos promoter. Nature 358:414-417.

Gille H, Kortenjann M, Thoma O, Moomaw C, Slaughter C, Cobb M, Shaw PE (1995) ERK phosphorylation potentiates Elk-1-mediated ternary complex formation and transactivation. EMBO J 14:951-962.

Ginty DD (1997) Calcium regulation of gene expression. Isn't that spatial? Neuron 18:183-186.

Ginty DD, Bading H, Greenberg ME (1992) Trans-synaptic regulation of gene expression. Curr Opin Neurobiol 2:312-316.

Gonzalez GA, Montminy MR (1989) Cyclic AMP stimulates somatostatin gene transcription by phosphorylation of CREB at serine 133. Cell 59:675-680.

Hardingham GE, Chawla S, Johnson CM, Bading H (1997) Distinct functions of nuclear and cytoplasmic calcium in the control of gene expression. Nature 385:260-265.

Hill CS, Marais R, John S, Wynne J, Dalton S, Treisman R (1993) Functional analysis of a growth factor-responsive transcription factor complex. Cell 73:395-406.

Hipskind RA, Rao VN, Mueller CGF, Reddy ESP, Nordheim A (1991) Ets-related protein Elk-1 is homologous to the c-fos regulatory factor p62TCF. Nature 354:531-534.

Hipskind RA, Baccarini M, Nordheim A (1994a) Transient activation of RAF-1, MEK, and ERK2 coincides kinetically with ternary complex factor phosphorylation and immediate-early gene promoter activity in vivo. Mol Cell Biol 14:6219-6231.

Hipskind RA, Büscher D, Nordheim A, Baccarini M (1994b) Ras/MAP kinase-dependent and -independent signaling pathways target distinct ternary complex factors. Genes Dev 8:1803-1816.

Impey S, Mark M, Villacres EC, Poser S, Chavkin C, Storm DR (1996) Induction of CRE-mediated gene expression by stimuli that generate long-lasting LTP in area CA1 of the hippocampus. Neuron 16:673-982.

Janknecht R, Nordheim A (1996) Regulation of the c-fos promoter by the ternary complex factor Sap-1a and its coactivator CBP. Oncogene 12:1961-1969.

Janknecht R, Zinck R, Ernst WH, Nordheim A (1994) Functional dissection of the transcription factor Elk-1. Oncogene 9:1273-1278.

Johnson CM, Hill CS, Chawla S, Treisman R, Bading H (1997) Calcium controls gene expression via three distinct pathways that can function independently of the ras/mitogen-activated protein kinases (ERKs) signaling cascade. J Neurosci 17:6189-6202.

Kurino M, Fukunaga K, Ushio Y, Miyamoto E (1995) Activation of mitogen-activated kinase in cultured rat hippocampal neurons by stimulation of glutamate receptors. J Neurochem 65:1282-1289.

Kwak SP, Hakes DJ, Martell KJ, Dixon JE (1994) Isolation and characterization of a human dual specificity protein-tyrosine phosphatase gene. J Biol Chem 269:3596-3604.

Kwok RPS, Lundblad JR, Chrivia JC, Richards JP, Bachinger HP, Brennan RG, Roberts SG, Green MR, Goodman RH (1994) Nuclear protein CBP is a coactivator for the transcription factor CREB. Nature 370:223-226.

Lev S, Moreno H, Martinez R, Canoll P, Peles E, Musacchio JM, Plowman GD, Rudy B, Schlessinger J (1995) Protein tyrosine kinase PYK2 involved in $\mathrm{Ca}^{2+}$-induced regulation of ion channel and MAP kinase functions. Nature 376:737-745.

Liste I, Rozas G, Guerra MJ, Labandeira-Garcia JL (1995) Cortical stimulation induces Fos expression in striatal neurons via NMDA glutamate and dopamine receptors. Brain Res 700:1-12.

Marais R, Wynne J, Treisman R (1993) The SRF accessory protein Elk-1 contains a growth factor-regulated transcriptional activation domain. Cell 73:381-393.

Matthews RP, Guthrie CR, Wailes LM, Zhao X, Means AR, Mc Knight GS (1994) Calcium/calmodulin-dependent gene expression. Mol Cell Biol 14:6107-6116.

McGeorge AJ, Faull RLM (1987) The organization and collateralization of corticostriate neurons in the motor and sensory cortex of the rat brain. Brain Res 423:318-324.

Miranti CK, Ginty DD, Huang G, Chatila T, Greenberg ME (1995) Calcium activates serum response factor-dependent transcription by a ras- and Elk-1-independent mechanism that involves a $\mathrm{Ca}^{2+}$ calmodulin-dependent kinase. Mol Cell Biol 15:3672-3684.

Noguchi T, Metz R, Chen L, Mattei MG, Carrasco D, Bravo R (1993) Structure, mapping, and expression of erp, a growth factor-inducible gene encoding a nontransmembrane protein tyrosine phosphatase and effect of ERP on cell growth. Mol Cell Biol 13:5195-5205.

Norman C, Runswick M, Pollok R, Treisman R (1988) Isolation and properties of cDNA clones encoding SRF, a transcription factor that binds to the c-fos serum response element. Cell 55:989-1003.

Ortiz J, Harris HW, Guitart X, Terwilliger RZ, Haycock JW, Nestler EJ (1995) Extracellular signal-regulated protein kinases (ERKs) and ERK kinase (MEK) in brain: regional distribution and regulation by chronic morphine. J Neurosci 15:1285-1297.

Pang L, Sawada T, Decker SJ, Saltiel AR (1995) Inhibition of MAP kinase kinase blocks the differentiation of $\mathrm{PC} 12$ cells induced by nerve growth factor. J Biol Chem 270:13585-13588.

Paxinos G, Watson C (1986) The rat brain in stereotaxic coordinates, 2nd Ed. New York: Academic.

Reubi JC, Cuenod M (1979) Glutamate release in vitro from corticostriatal terminals. Brain Res 176:185-188.

Rivera VM, Miranti RP, Misra RP, Ginty DD, Chen RH, Blenis J, Greenberg ME (1993) A growth factor-induced kinase phosphorylates the serum response factor at a site that regulates its DNA binding activity. Mol Cell Biol 13:6260-6273.

Robertson LM, Kerpolla TK, Vendrell M, Luk D, Smeyne RJ, Bocchiara C, Morgan JI, Curran T (1995) Regulation of c-fos expression in transgenic mice requires multiple interdependent transcription control elements. Neuron 14:214-252.

Rosen LB, Ginty DD, Weber MJ, Greenberg ME (1994) Membrane depolarization and calcium influx stimulate MEK and MAP kinase via activation of ras. Neuron 12:1207-1221.

Schröter H, Mueller CGF, Meese K, Nordheim A (1990) Synergism in ternary complex formation between the dimeric glycoprotein $\mathrm{p} 67^{\mathrm{SRF}}$, polypeptide $\mathrm{p} 62^{\mathrm{TCF}}$, and the c-fos serum response element. EMBO J 9:1123-1130.

Seger R, Krebs EG (1995) The MAPK signaling pathway. FASEB J 9:726-735.

Sgambato V, Abo V, Rogard M, Besson MJ, Deniau JM (1997) Effect of electrical stimulation of the cerebral cortex on the expression of the Fos protein in the basal ganglia. Neuroscience 81:93-112.

Sgambato V, Vanhoutte P, Pagès C, Rogard M, Hipskind RA, Besson MJ, Caboche J (1998) In vivo expression and regulation of Elk-1, a target of extracellular regulated kinase signaling pathway, in the adult rat brain. J Neurosci 18:214-226. 
Shaw PE, Schröter H, Nordheim A (1989) The ability of a ternary complex to form over the serum response element correlates with serum inducibility of the human $c$-fos promoter. Cell 56:563-572.

Sheng M, Greenberg ME (1990) The regulation and function of c-fos and other immediate early genes in the nervous system. Neuron 4:477-485.

Sheng M, McFadden G, Greenberg ME (1990) Membrane depolarization and calcium induce c-fos transcription via phosphorylation of transcription factor CREB. Neuron 4:571-582.

Sheng M, Thompson MA, Greenberg ME (1991) CREB: a $\mathrm{Ca}^{2+}$ regulated transcription factor phosphorylated by calmodulindependent kinases. Science 252:1427-1430.

Siciliano JC, Toutant M, Derkinderen P, Sasaki T, Girault JA (1996) Differential regulation of proline-rich tyrosine kinase $2 /$ cell adhesion kinase $\mathrm{b}(\mathrm{PYK} 2 / \mathrm{CAKb})$ and pp125FAK by glutamate and depolarization in rat hippocampus. J Biol Chem 271:28942-28946.

Smith AD, Bolam JP (1990) The neural network of the basal ganglia as revealed by the study of synaptic connections of identified neurons. Trends Neurosci 13:259-265.

Strugill TW, Ray LB, Erikson E, Maller JE (1988) Insulin-stimulated MAP-2 kinase phosphorylates and activates ribosomal protein S6 kinase II. Nature 334:715-718.

Sugimoto T, Stewart S, Guan KL (1997) The calcium/calmodulindependent protein phosphatase calcineurin is the major Elk-1 phosphatase. J Biol Chem 272:29415-29418.

Sun H, Charles CH, Lau LF, Tonks NK (1993) MKP-1 (3CH134), an immediate early gene product, is a dual specificity phosphatase that dephosphorylates MAP kinase in vivo. Cell 75:487-493.

Sun P, Enslen H, Myung PS, Maurer RA (1994) Differential activation of CREB by $\mathrm{Ca}^{2+} /$ calmodulin-dependent protein kinases type II and type IV involves phosphorylation of a site that negatively regulates activity. Genes Dev 8:2527-2539.

Treisman R (1986) Identification of a protein-binding site that mediates the transcriptional response of the c-fos gene to serum factors. Cell 4:567-574.

Treisman R (1992) The serum response element. Trends Biochem Sci 17:423-426.

Treisman R (1995) Journey to the surface of the cell: fos regulation and the SRE. EMBO J 14:4905-4913.

Winder DG, Mansuy IM, Osman M, Moallem TM, Kandel ER (1998) Genetic and pharmacological evidence for a novel, intermediate phase of long-term potentiation suppressed by calcineurin. Cell 92:25-37.

Xia Z, Dudek H, Miranti CK, Greenberg ME (1996) Calcium influx via the NMDA receptor induces immediate early gene transcription by a MAP kinase/ERK-dependent mechanism. J Neurosci 16:5425-5436.

Xing J, Ginty DD, Greenberg ME (1996) Coupling of the ras-MAPK pathway to gene activation by RSK2, a growth-factor-regulated CREB kinase. Science 273:959-963.

Yakel JL (1997) Calcineurin regulation of synaptic function: from ion channels to transmitter release and gene transcription. Trends Pharmacol Sci 18:124-134.

Yamamoto KK, Gonzales GA, Biggs WH, Montminy ME (1989) Phosphorylation-induced binding and transcriptional efficacy of nuclear factor CREB. Nature 334:494-498.

Zinck R, Hipskind RA, Pingoud V, Nordheim A (1993) c-fos transcriptional activation and repression correlate temporally with the phosphorylation status of TCF. EMBO J 12:2377-2387. 